\title{
Heavy Metal Stabilization in Soils using Waste Resources - A Critical Review
}

\author{
Jung Eun Lim • Deok Hyun Moon · Kwon-Rae Kim · Jae E Yang • Sang Soo Lee \\ - Yong Sik Ok*
}

\section{폐자원을 이용한 중금속 오염토양의 안정화 - 총설}

임정은 · 문덕현 · 김권래 · 양재의 · 이상수 · 옥용식*

\begin{abstract}
Stabilization of metals in contaminated soils using various waste materials has been reported. Alkaline materials (limes, shells, industrial byproducts, etc.), phosphorous (P) containing materials (animal bones, phosphate rock, etc.), organic materials (composts, manures, biochars, etc.) and others (zerovalent iron, zeolite, etc.) were widely evaluated to ensure its effectiveness/applicability of stabilization of metals in soils. Stabilization mechanisms of those materials above were partially revealed, but the related literatures are still lacked and not sufficient for approaching to long-term stability/applicability in the field. The aims of this review are to summarize current knowledge of metal stabilization in contaminated soils using various waste materials and to suggest a direction for future field research.
\end{abstract}

J. E. Lim $\cdot$ J. E. Yang $\cdot$ S. S. Lee $\cdot$ Y. S. Ok

Korea Biochar Research Center \& Department of Biological Environment, Kangwon National University, Chuncheon 200-701, Republic of Korea

D. H. Moon

Department of Environmental Engineering, Chosun University, Gwangju 501-759, Republic of Korea

\section{K.-R. Kim}

Department of Agronomy and Medicinal Plant Resources, Gyeongnam National University of Science and Technology, Jinju 660-758, Republic of Korea

*Corresponding author (Y. S. Ok: soilok@kangwon.ac.kr)

This is an Open Access article distributed under the terms of the Creative Commons Attribution Non-Commercial License (http://creativecommons. org/licenses/by-nc/3.0/) which permits unrestricted non-commercial use, distribution, and reproduction in any medium, provided the original work is properly cited.
Keywords adsorbent $\cdot$ bioavailability $\cdot$ biochar $\cdot$ soil pollution $\cdot$ soil remediation $\cdot$ stabilizer $\cdot$ waste management

\section{중금속 오염토양의 정화기술}

중금속에 의한 토양오염은 휴-폐광산 인근 농경지 $(\mathrm{Ok}$ 등, 2011a; Lim 등, 2013a), 군부대 사격장(Ahmad 등, 2012a; 2014a), 제련소 및 산업부지 등에서 보고되고 있다(Hong 등, 2009; Baker 등 2012). 오염된 농작물의 섭취, 직접 흡입 등을 통해 인간 체내로 유입되는 중금속은 인간 건강에 심각한 위해 성을 나타낸다(Kumpiene 등, 2008; Lee 등, 2013b). 이로 인해 중금속 오염 정화를 위한 다양한 방법들이 적용되어 왔다. 기 존의 중금속 오염토양에 대한 정화 방법은 굴착(excavation), 매 립(landfill) 및 토양 세척법(soil washing), 동전기법(electrokinetic separation) 등이 있으며 이는 토양 중금속의 농도와 위해성을 낮추는 데에 효과적이긴 하나 비용이 많이 소모된다는 단점이 있다(Basta와 McGowen, 2004; Hartley 등, 2004; Kumpiene 등, 2008; Lim 등, 2013a). 특히 기존의 정화 방법은 토양에 대한 물리 - 화학 - 생물학적 특성에 대한 고려없이 단순히 법 적기준치 이하로 토양 중금속의 농도를 낮추는 것에 초점을 맞 추고 있어, 정화 후에는 토양이 가진 고유의 생태적 기능을 상 실하게 된다(Ok 등, 2011c; 2011d).

안정화(stabilization) 방법은 원위치(in situ)에서 적용이 가능 하며 흡착(adsorption)이나 침전(precipitation) 등을 통해 용해성 (soluble) 오염물질의 농도를 저감하는 정화방법으로 기존 방법 에 비해 비용소모가 적으며 용해도(solubility)가 낮은 광물 또 는 침전물의 형성을 통해 오염물질의 생물유효도(bioavailability) 및 추출도(extractablity)를 낮출 수 있다(Basta와 McGowen, 2004). 특히 토양 개량제를 사용하는 안정화 방법은 적용의 용 
이성, 경제성, 화학적 불용성으로 인해 중금속 오염토양의 정화 에 널리 사용되고 있으며, 고유의 생태적 기능도 유지할 수 있 어 낮은 수준으로 오염된 농경지 등에 적용되고 있다(Zhao와 Masaihiko, 2007). 중금속 안정화를 위하여 토양 개량제로 사용 되는 대표적인 물질로는 알칼리물질이 있으며 이는 토양의 $\mathrm{pH}$ 를 상승시킨다. $\mathrm{pH}$ 가 상승하는 경우 토양의 음전하(negative charge)가 증대되어 양이온성 중금속의 토양 흡착이 증가한다 (Zhao와 Masaihiko, 2007). 이와 함께 토양 $\mathrm{pH}$ 가 알칼리 조건 인 경우 중금속 양이온은 수산화물(hydroxides) 침전을 형성하면 서 안정화될 수 있다(Zhao와 Masaihiko, 2007; Ok 등, 2010). 이 외에도 납 $(\mathrm{Pb})$ 의 안정화를 위해 인 함유물질(phosphoruscontaining materials)을 사용하는 경우 불용성의 pyromorphite $\left[\mathrm{Pb}_{5}\left(\mathrm{PO}_{4}\right)_{3} \mathrm{X} ; \mathrm{X}=\mathrm{Cl}, \mathrm{OH}, \mathrm{F}, \mathrm{Br}\right.$ 등 $]$ 가 형성되며 이 경우 생물 유효도는 매우 낮은 것으로 알려져 있다(Kumpiene 등, 2008). 또한 철(Fe) 함유물질의 처리를 통한 비소(As)의 안정화 등도 보고되고 있으며(Hartley 등, 2004; Kumpiene 등, 2006), 최근 에는 바이오차(biochar)를 토양 개량제로 활용한 중금속 안정화 연구들이 보고되고 있다(Moon 등, 2013b; Ahmad 등, 2014a; 2014b).

오염부지 정화과정에서 정화기법의 순환경적이익(net environmental benefit)을 극대화하기 위한 녹색정화(green remediation)의 개념 이 확산되고 있다(USEPA, 2008; Tomasevic 등, 2013). 녹색정 화는 정화과정에서 환경에 대한 영향과 에너지의 투입을 최소 화한다. 이는 천연자원을 사용하며 에너지 효율적인 방법으로 정화과정에서 야기되는 환경에 대한 부정적인 영향을 줄이고 오 염물질을 근원에서 제거 또는 최소화함과 동시에 정화과정에서 발생하는 폐기물을 저감할 수 있다(USEPA, 2008). 특히 농축 수산 부산물, 산업부산물 등과 같은 폐자원은 기존의 개량제에 비해 확보비용이 경제적일 뿐만 아니라 대량으로 확보가 가능 하다. 그러므로 이를 토양 개량제로 오염정화에 활용하는 경우 기존에 부산물 폐자원이 재활용 없이 폐기될 때 발생하는 여러 가지 환경적 문제들에 대한 해결방안과 함께 토양오염의 정화 라는 녹색정화의 개념을 달성할 수 있다.

토양 내 중금속 안정화를 위해 사용되는 개량제들에 대한 선 행 리뷰논문들이 다양하게 보고되고 있다. Kumpiene 등(2008) 은 토양 내 특정 중금속( $\mathrm{As}, \mathrm{Cr}, \mathrm{Cu}, \mathrm{Pb}, \mathrm{Zn})$ 안정화에 사용되 는 기존 개량제들의 작용기작에 대해 보고하였으며, 이와 함께 장기적 안정성 평가 및 실제 현장 실험의 필요성을 언급하였다. Park 등(2011b)은 바이오 고형물(biosolids), 도시고형폐기물 (MSW, municipal solid waste) 등의 유기성 개량제(organic amendment)에 의한 중금속 오염토양의 생물정화(bioremediation) 기술에 대해 보고하였다. 이 연구에서 유기물질 처리에 의한 중 금속 불용화(immobilization), 환원(reduction), 휘발(volatilization) 및 식물근권(rhizosphere)에서의 $\mathrm{pH}$ 변화, 유기산(organic acid), 미생물군집(microbial community) 변화 등에 대해 보고하였다 (Park 등, 2011b). Bolan 등(2014)은 현재까지 보고된 다양한 개량제들을 중금속 안정화제 및 가용화제로 분류하였다. 안정화 용 개량제로는 $\mathrm{KH}_{2} \mathrm{PO}_{4}$, 인광석( $\mathrm{PR}$, phosphate rock) 등의 인 함유물질, 석회물질 $\left[\mathrm{Ca}(\mathrm{OH})_{2}, \mathrm{CaCO}_{3}\right.$ 등], 유기물질(manure, compost 등), 금속산화물( $\mathrm{Mn}$ 및 $\mathrm{Fe}$ oxides 등)이 중금속 안정 화제로 사용됨을 보고하였다. 한편 가용화제들로는 EDTA (ethylene diaminetetra acetic acid), EDDS (ethylene diamine$\mathrm{N}, \mathrm{N}$-disuccinic acid) 등의 킬레이트제 및 oxalic acid, citric acid 등의 유기산이 사용되어 식물추출(phytoextraction), 토양세척 등
의 효율성을 높이는 데 사용될 수 있음을 보고하였다. 이와 함 께 향후에 1) 안정화제와 가용화제의 토양 처리 후 식물에 대 한 생리학(physiology) 관점에서의 연구, 2) 현장에서의 안정화 제와 가용화제 처리 연구, 3) 진보된 분광학적 기법 사용(방사 광가속기 등)을 통한 안정화제와 가용화제의 단기 및 장기 효 율성 평가, 4) 토양개량제 처리 후 위해성 저감을 평가하기 위 한 인체유효도(human bioavailability), 식물독성(phytotoxicity) 평가 등이 필요함을 보고하였다(Bolan 등, 2014).

기존 리뷰들에서는 특정 중금속 원소 $(\mathrm{As}, \mathrm{Cr}, \mathrm{Cu}, \mathrm{Pb}, \mathrm{Zn})$ 및 기존의 대표적인 물질들의 주요 안정화 기작을 상세하게 다루 고 있으나 부산물 폐자원을 활용한 개량제에 대한 내용은 비중 있게 다루고 있지 못하다. 이에 본 논문에서는 지난 20 년간 보 고된 토양 중금속 안정화용 부산물 폐자원 개량제에 대한 대표 적인 논문들을 살펴보고 각각의 개량제 별로 보고된 중금속 안 정화 작용기작에 대해 정리하였으며 향후 연구방향에 대해 고 찰해 보고자 하였다.

\section{다양한 개량제를 활용하는 중금속 안정화 연구}

\section{알칼리물질(Alkaline materials)}

알칼리물질은 중금속 안정화를 위하여 토양 개량제로 사용되는 대표적인 물질로 토양에 처리되어 $\mathrm{pH}$ 를 상승시킨다. 이 때 토 양의 음전하가 증대되어 양이온성 중금속의 토양 흡착이 증가 한다(Zhao와 Masaihiko, 2007). 또한 알칼리 조건의 토양 $\mathrm{pH}$ 에 서 중금속 양이온은 수산화물(hydroxides) 침전을 형성하는데 이 러한 기작들을 통해 토양 중에서 안정화될 수 있다(Zhao와 Masaihiko, 2007; Ok 등, 2010). 이와 함께 증가된 $\mathrm{pH}$ 조건에서 점토(clay)로부터 $\mathrm{Al}, \mathrm{Si}$ 의 방출을 통해 $\mathrm{CAH}$ (calcium aluminate hydrate), $\mathrm{CSH}$ (calcium silicate hydrate)와 같은 포졸란 반응 산물(pozzolanic reaction products)의 형성 및 ettringite $\left[\mathrm{Ca}_{6} \mathrm{Al}_{2}\right.$ $\left(\mathrm{SO}_{4}\right)_{3}(\mathrm{OH})_{12} \cdot 26 \mathrm{H}_{2} \mathrm{O}$ ]의 형성에 의해 토양 내 중금속이 안정화 될 수 있다(Gougar 등, 1996; Moon 등, 2013a).

패각류 및 난각류(Shells and Egg shells). 최근 패각류 및 난 각류 폐자원을 토양 개량제로 재활용하는 연구가 활발하게 진 행되고 있다. 패각류로는 굴껍질(oyster shell)과 홍합껍질(mussel shell), 난각류로는 달걀껍질(eggshell)이 개량제로 활용되고 있으 며, 대표적인 연구결과들은 다음과 같다.

$\mathrm{Lim}$ 등(2009)은 토양 내 비소를 안정화하는 연구에서 $\mathrm{CaCO}_{3}$ 가 주성분인 굴껍질과 달걀껍질을 토양 무게 대비 $1,5 \mathrm{wt} \%$ 수 준으로 처리하였을 때, $\mathrm{Ca}-\mathrm{As}$ 화합물이 형성됨에 따라 $1 \mathrm{M}-\mathrm{HCl}$ 용출성 비소의 농도가 굴껍질과 달걀껍질 $5 \mathrm{wt} \%$ 처리구에서 무 처리구 대비 각각 $10.8,9.2 \%$ 감소함을 보고하였다 $(\mathrm{Lim}$ 등, 2009). Moon 등(2009)도 토양 내 비소 안정화 연구에서 굴껍 질과 소성(calcination)한 굴껍질을 1-20 wt\% 수준으로 토양에 처리하였을 때 최대 정화효율은 굴껍질과 소성한 굴껍질 20 $\mathrm{wt} \%$ 처리구에서 각각 $47,96 \%$ 임을 보고하였다. 이에 대해 Moon 등(2009)은 SEM-EDX (scanning electron microscope-energy dispersive X-ray spectrometer)를 활용한 elemental dot mapping 분석을 통해 비소와 $\mathrm{O}, \mathrm{Si}, \mathrm{Al}, \mathrm{Ca}$ 간의 연관성에 근거하여 $\mathrm{Si}$, $\mathrm{Al}$ 에 의한 $\mathrm{CSH}, \mathrm{CAH}$ 와 같은 포졸란 반응 산물의 생성 및 용 해도가 낮은 $\mathrm{Ca}-\mathrm{As}$ 로의 침전에 의한 안정화임을 보고하였다. 또한 Moon 등(2011)은 비소로 오염된 광미(mine tailing)의 정 화를 위해 굴껍질과 소성 굴껍질을 처리하였다. 연구결과 굴껍 
질 $30 \mathrm{wt} \%$ 및 소성 굴껍질 $25 \mathrm{wt} \%$ 처리구에서 $1 \mathrm{M}-\mathrm{HCl}$ 가용 성 비소가 무처리구 대비 각각 $72,99 \%$ 이상 감소하였다. SEM-EDX 분석을 통해 바늘(needle) 및 어뢰(torpedo) 형태가 관찰되었고, 이에 대한 elemental dot mapping 분석결과 $\mathrm{Ca}$, $\mathrm{As}, \mathrm{O}$ 간에 연관성이 관찰되어 소성 굴껍질 처리에 의한 ettringite 내 $\mathrm{AsO}_{4}{ }^{3-}$ 치환 및 arsenate apatite $\left[\mathrm{Ca}_{5}\left(\mathrm{AsO}_{4}\right)_{3} \mathrm{OH}\right]$ 형성이 안정화의 주된 작용 기작임을 보고하였다(Moon 등, 2011).

Moon 등(2010)은 군부대 사격장 토양(shooting range soil) 내 납 안정화를 위해 굴껍질 및 소성한 굴껍질을 처리하는 연 구에서 천연 굴껍질 보다는 소성한 굴껍질의 처리가 용출되는 납 농도 저감에 더욱 효율적임을 보고하였다. SEM-EDX를 활 용한 elemental dot mapping 분석결과 납은 $\mathrm{Si}, \mathrm{Al}$ 과 상관성을 보였는데 이는 $\mathrm{CSH}, \mathrm{CAH}$ 의 생성에 의한 납의 안정화 결과라 고 보고하였다. 특히 개량제의 입경이 작을수록 납의 용출농도 가 감소하여 안정화 효율이 더 높음을 보고하였다(Moon 등, 2010). Ok 등(2010)은 광미로 인해 납과 카드뮴 $(\mathrm{Cd})$ 으로 오염 된 농경지의 정화 연구에서 굴껍질과 소성한 굴껍질을 1-5 $\mathrm{wt} \%$ 수준으로 처리하였다. 항온배양 30 일 후 토양의 $\mathrm{pH}$ 는 무 처리구 $(\mathrm{pH} 6.5)$ 와 비교 시 굴껍질 $(\mathrm{pH} 8.3)$ 및 소성 굴껍질 처 리구 $(\mathrm{pH} 12.5)$ 에서 상승하였으며 $0.1 \mathrm{M}-\mathrm{HCl}$ 용출성 카드뮴과 납 은 유의한 수준으로 감소하였다. 또한 천연 굴껍질과 소성 굴 껍질 $5 \mathrm{wt} \%$ 처리구에서 납은 $95 \%$ 이상 감소하였으며, 소성 굴 껍질의 처리가 카드뮴과 납의 안정화에 더욱 효과적인 것으로 나타났다. 이는 알칼리 $\mathrm{pH}$ 조건에서 불용성 중금속 수산화물 생성 및 $\mathrm{pH}$ 상승에 의한 토양표면의 순 음전하(net negative charge) 증대에 따른 양이온성 중금속 흡착 증가에 기인한다고 보고하였다(Zhao와 Masaihiko, 2007; Ok 등, 2010). 이와 유사 하게 Ahmad 등(2013)은 굴껍질과 소성 굴껍질을 사격장 토양 내 안티몬 $(\mathrm{Sb})$ 의 안정화에 사용하였다. 연구결과 굴껍질 처리구 의 경우 $\mathrm{pH} 8$ 부근에서 토양입자로부터 안티몬의 탈착 (desorption)으로 인해 용출농도가 증가하였으며, 소성 굴껍질 처 리구의 경우 calcium antimonite $\left[\mathrm{Ca}\left(\mathrm{Sb}(\mathrm{OH})_{6}\right)_{2}\right]$ 로의 침전 및 ettringite 형성 후 치환에 의해 안정화됨을 보고하였다.

Ahmad 등(2012a)은 사격장 토양 내 납의 안정화를 위해 달 갈껍질과 소성한 달갈껍질을 $2.5-30 \mathrm{wt} \%$ 수준으로 처리하였다. 항온배양 28 일 후 연속추출을 통한 중금속 화학종 분획화를 실 시한 결과 교환성(exchangeable) 납은 감소하며 탄산염 분획 (carbonate fraction)이 증가하였다. 기존 연구결과 및 열역학모 델링, $\mathrm{SEM}-\mathrm{EDX}$ 분석을 통해 이는 $\mathrm{pH}$ 상승에 의한 음전하의 증대, 이온교환(ion exchange) 및 수산화물로의 침전, 탄산염 (carbonates)으로의 공침전(co-precipitation), $\mathrm{CSH}$ 로의 entrapment 에 의한 안정화 기작임을 보고하였다(Ahmad 등, 2012a). 이와 유사하게 Ahmad 등 $(2012 \mathrm{c})$ 은 사격장 토양 내 납과 구리 $(\mathrm{Cu})$ 의 안정화 연구에서 달걀껍질, 굴껍질, 홍합껍질을 토양에 처리하 였다. 연구결과 물-용출성(water extractable) 납은 달걀껍질 처 리구 $(2.5 \mathrm{wt} \%)$ 에서 무처리구 대비 $45 \%$ 감소, 굴껍질 처리구 $(2.5$ $\mathrm{wt} \%)$ 에서 $38.6 \%$ 감소, 홍합껍질 처리구 $(10 \mathrm{wt} \%)$ 에서 $22.7 \%$ 감 소하였으며, 이는 개량제 처리 후 토양 $\mathrm{pH}$ 상승에 따른 불용성 의 납 수산화물 형성에 기인한다고 하였다. 반면에 구리는 모 든 처리구에서 무처리구 대비하여 증가하였는데 이는 토양 $\mathrm{pH}$ 상승에 의해 토양 내 용존유기물질(dissolved organic matter)이 늘어나면서 $\mathrm{Cu}$-용존유기탄소(DOC, dissolved organic carbon) 복합체 형성이 증대된 것에 기인한 것이라고 하면서 이에 대한 주의가 필요하다고 하였다(Ahmad 등, 2012c).
Lee 등(2013a)은 오염토양에 소성 굴껍질과 석탄광산배수슬러 지(CMDS, coal mine drainage sludge)를 혼합처리 $(5+3 \mathrm{wt} \%)$ 하 는 연구에서 처리 28 일 후 $0.1 \mathrm{M}-\mathrm{HCl}$ 용출성 비소, 납, 구리의 농도가 무처리구 대비 각각 $93.7,99.9,91.2 \%$ 까지 감소함을 보 고하였다. 이는 $\mathrm{CMDS}$ 에 의한 $\mathrm{As}-\mathrm{Fe}$ complex형성 및 소성 굴 껍질 처리 후 $\mathrm{Ca}-\mathrm{As}$ 화합물, $\mathrm{CSH}, \mathrm{CAH}$ 형성에 의한 안정화 라고 보고하였다. 이와 함께 여러 가지 원소들로 오염된 토양 의 효과적인 정화를 위하여 모든 원소들에 대한 alkali-soluble 분획의 가용화(mobilization) 및 $\mathrm{DOC}$ 와 관계된 구리의 교환성 분획에 대한 추가연구가 필요하다고 보고하였다(Lee 등, 2013a). 산업부산물(Industrial by-products). 산업부산물은 최근 다양한 재활용 방안이 모색되고 있으며 이 중에서도 알칼리적 특성에 기초하여 토양 내 중금속 안정화를 위한 개량제로 활용되고 있 다. 그 종류로는 알루미늄 및 시멘트 생산공정의 부산물인 레 드머드(RM, red mud) 및 시멘트 키른 더스트(CKD, cement kiln dust)와 연소부산물로 발생하는 비산재(FA, fly ash), 바닥 재(BA, bottom ash), 제강슬래그(FS, furnace slag) 등이 사용되 고 있으며, 대표적인 연구결과들은 다음과 같다.

Lombi 등(2004)은 토양 내 구리와 비소의 안정화를 위하여 철(수)산화물을 다량 함유한 $\mathrm{RM}$ 을 토양에 $2 \mathrm{wt} \%$ 수준으로 처 리하였다. 연구결과 구리와 비소는 RM 처리에 의하여 무처리 구 대비 상당량 감소하였는데 이는 알칼리물질인 $\mathrm{RM}$ 처리에 의한 토양 $\mathrm{pH}$ 상승에 기인한 결과이며, 특히 비소의 경우 증가 된 토양 내 철 산화물로의 흡착을 통해 감소함을 보고하였다. 이 같은 연구결과를 통해 Lombi 등(2004)는 양이온성인 구리 와 음이온성인 비소로 오염된 토양의 동시정화를 위해 철이 다 량 함유된 산업부산물의 사용을 제안하였다. Garau 등(2007)은 광산활동으로 오염된 토양의 납, 카드뮴, 아연 $(\mathrm{Zn})$ 의 안정화를 위하여 RM을 처리하는 연구를 수행하였다. 6개월 후 연속추출 을 통한 분획화 결과 RM 처리에 의하여 토양 내 납, 카드뮴, 아연은 생물유효성 분획(bioavailable fraction)이 감소하고 잔류 성 분획(residual fraction)이 증가하였다. 이는 RM 처리 후 토 양 $\mathrm{pH}$ 상승에 따른 중금속 침전과 유기물 및 $\mathrm{Fe} / \mathrm{Al}$ oxides로 의 중금속 흡착이 증대된 것에 기인한 결과라고 하였다. 특히 $\mathrm{RM}$ 의 구성광물인 cancrinite, hematite로의 흡착도 이에 대한 원 인임을 보고하였다(Garau 등, 2007). Gray 등(2006)은 RM 처 리 후 토양 내 중금속 $(\mathrm{Cd}, \mathrm{Cu}, \mathrm{Cr}, \mathrm{Ni}, \mathrm{Pb}, \mathrm{Zn})$ 의 안정화를 평 가하였다. 연구결과 $\mathrm{RM} 5 \mathrm{wt} \%$ 처리 후 $1 \mathrm{M}-\mathrm{NH}_{4} \mathrm{NO}_{3}$ 용출성 중금속의 함량이 감소하였는데 이는 알칼리성인 $\mathrm{RM}$ 처리에 의 한 토양 $\mathrm{pH}$ 상승 후 증대된 토양의 음전하 부위에 중금속 흡 착이 증가되었고, 흡착성 부위가 있는 $\mathrm{Fe}, \mathrm{Al}$ oxide를 함유한 $\mathrm{RM}$ 이 토양으로 도입된 것에 기인한 결과임을 보고하였다(Gray 등, 2006). 이와 유사하게 Lee 등(2009)은 폐광산 인근 농경지 토양에 $\mathrm{RM}$ 과 $\mathrm{FS}$ 를 처리하여 카드뮴, 납, 아연에 대한 안정화 효율성 평가를 실시하였다. 연구결과 중금속 용출이 감소하였는 데 이는 개량제 처리 후 $\mathrm{pH}$ 상승에 의한 토양 입자로의 중금 속 흡착 증대 및 $\mathrm{Fe}, \mathrm{Al}$ oxide를 함유한 RM과 $\mathrm{FS}$ 로의 특이흡 착(specific sorption), 화학흡착(chemisorption)에 의한 결과라고 하였다. RM 처리구의 경우 토양에서 상추(lettuce)로 전이되는 카드뮴, 납, 아연을 저감하는 것에 가장 효과적이었으며 감소율 은 무처리구 대비 각각 $86,58,73 \%$ 로 나타났다(Lee 등, 2009). 한편, RM 처리에 의해 일부 물-용출성 납이 증가하였는 데 이는 $\mathrm{RM}$ 투입 후 증가된 $\mathrm{DOC}$ 와 중금속 간의 용해성 유 기복합체(soluble organo-complexes) 형성 또는 DOC와 납의 경 
쟁 흡착에 기인한다고 하였다(Lee 등, 2009). 이와 함께 Lee 등 (2014)은 광미 내 중금속 $(\mathrm{Cd}, \mathrm{Cu}, \mathrm{Pb}, \mathrm{Zn})$ 안정화를 위해 $\mathrm{BA}$, $\mathrm{FS}, \mathrm{RM}$ 을 $2 \mathrm{wt} \%$ 수준으로 처리하였다. 연구결과 용출되는 중 금속 농도는 무처리구 대비하여 급격하게 감소하였는데 이는 알 칼리성 개량제 투입에 따른 중금속의 흡착증대, $\mathrm{Al}, \mathrm{Fe}, \mathrm{Mn}$ oxides와의 침전, 중금속 규산염(metal silicate)과 같은 광물형성, 광물표면으로의 확산(diffusion)에 기인한다고 하였다(Lee 등, 2014). 한편, $\operatorname{Lim}$ 등(2010)은 비소오염 토양의 정화를 위해 FS 를 처리하는 연구에서 FS 처리가 비소의 용출을 증가시켰는데 이는 FS에 함유된 인산과 토양 내 비소와의 경쟁 흡착에 의한 결과이며 이에 대한 주의가 필요하다고 하였다(Lim 등, 2010).

Kostarelos 등(2006)은 크롬 $(\mathrm{Cr})$ 오염 토양의 정화를 위해 FA 를 처리하였다. 연구결과 포졸란 반응 산물 $(\mathrm{CSH}, \mathrm{CAH})$ 내 물 리적 entrapment와 높은 $\mathrm{pH}$ 조건에서 공극 표면 흡착 증대로 인해 토양 내 초기 크롬 농도에 대비 $97.3-99.7 \%$ 의 안정화 효 과를 보고하였다(Kostarelos 등, 2006). 이와 유사하게 Kumpiene 등(2007)은 토양 내 구리와 납의 안정화를 위하여 $\mathrm{FA}$ 를 처리 하였다. 연구결과 $\mathrm{FA}$ 처리 후 물-용출성 구리와 납이 각각 $91.1,87.1 \%$ 까지 감소하였는데 이는 $\mathrm{pH}$ 상승 후 중금속의 이 동성 감소에 의한 것이라고 하였다(Kumpiene 등, 2007). 이와 함께 Dermatas와 Moon(2006)은 토양 내 크롬 안정화를 위해 FA와 quick lime을 혼합 처리하였으며, 이를 통해 TCLP (Toxicity characteristic leaching procedure) 용출성 크롬 농도가 감소하였는데 이는 $\mathrm{XRD}$ (X-ray diffraction) 분석결과 $\mathrm{Cr}(\mathrm{VI})$ 의 $3 \mathrm{CaOAl}_{2} \mathrm{O}_{3} 0.5 \mathrm{CaCrO}_{4} 0.5 \mathrm{CaSO}_{4} \cdot \mathrm{nH}_{2} \mathrm{O}$ 의 침전형성에 의한 안정화 라고 보고하였다. 또한 Moon 등(2013c)은 사격장 토양 내 납 과 구리의 동시 안정화를 위해 $\mathrm{FA}$ (class $\mathrm{C}, \mathrm{CaO}$ 함량 $20 \%$ 이 상)와 소성 굴껍질을 혼합 처리하였다. 연구결과 혼합 처리구에 서 TCLP 용출성 납과 구리는 무처리구 대비 각각 98 및 $96 \%$ 이상 감소하였으며 이는 높은 $\mathrm{pH}$ 조건 $(\mathrm{pH}>12)$ 에서 ettringite 및 $\mathrm{CAH}, \mathrm{CSH}$ 생성에 의한 결과임을 $\mathrm{SEM}-\mathrm{EDX}$ 를 활용한 elemental dot mapping분석을 통해 보고하였다(Moon 등, 2013c).

이 외에도 Zhao와 Masaihiko(2007)은 토양 내 카드뮴 정화 연구에서 ALC(Autoclave Light-weight Concrete: 경량기포 콘 크리트) 생산 부산물인 porous hydrated calcium silicate를 처리 하였을 때, 벼의 줄기(straw)와 현미(brown rice)로 전이되는 카 드뮴이 각각 최대 $92.2,92.0 \%$ 까지 감소함을 보고하였다. 이는 개량제 처리에 의한 토양 $\mathrm{pH}$ 상승효과와 함께 개량제에 함유 된 규산염(silicate)에 의한 토양 내 카드뮴 화학종 변화 및 토 양으로의 흡착증진에 의한 결과라고 보고하였다(Zhao와 Masaihiko, 2007). 한편, Moon 등(2008)은 포틀랜드 시멘트 제 조공정에서 부산물로 발생하는 $\mathrm{CKD}$ 를 토양에 처리하여 비소 에 대한 안정화 연구를 실시하였다. 연구결과 $\mathrm{CKD}$ 처리에 의 해 TCLP로 용출성 비소는 감소하였으며 이는 SEM-EDX 및 $\mathrm{XRPD}(\mathrm{X}$-ray powder diffraction) 분석을 통해 $\mathrm{As}(\mathrm{III})$ 의 경우 calcium arsenite (Ca-As-O), $\mathrm{As}(\mathrm{V})$ 의 경우 sodium calcium arsenate hydrate $\left(\mathrm{NaCaAsO}_{4} \cdot 7.5 \mathrm{H}_{2} \mathrm{O}\right)$ 의 침전물 형성을 통해 안 정화됨을 보고하였다(Moon 등, 2008).

석회(Limes). 석회물질은 토양의 $\mathrm{pH}$ 를 상승시키는 대표적인 물 질로 중금속 정화를 위해 가장 널리 사용되고 있으며 토양 $\mathrm{pH}$ 상승 및 중금속의 탄산염 침전 등 여러 가지 기작을 통해 토양 내 중금속을 안정화 한다(Lee 등, 2004). 석회물질로는 $\mathrm{CaCO}_{3}$ (calcium carbonate, lime stone), $\mathrm{Ca}(\mathrm{OH})_{2}$ (calcium hydroxide, slaked lime), $\mathrm{CaO}$ (calcium oxide, quick lime)이 있으며, 대 표적인 연구결과들은 아래와 같다.

Basta와 McGowen(2004)은 제련 공장 인근 토양 중 카드뮴, 납, 아연의 정화를 위하여 $\mathrm{CaCO}_{3}$ 를 $170 \mathrm{~g} / \mathrm{kg}$ 수준으로 처리하 였다. 컬럼용출실험(column leaching test) 결과 카드뮴, 납, 아 연의 용출농도가 각각 $55,45.2,21.9 \%$ 감소하였는데 이는 $\mathrm{CaCO}_{3}$ 처리에 의한 중금속 탄산염 침전물 생성에 기인한 결과 라고 하였다(Basta와 McGowen, 2004). 또한 Lee 등(2004)은 공장폐수로 인해 카드뮴, 납으로 오염된 농촌지역 토양에 $\mathrm{CaCO}_{3}$ 를 10,20 tons/ha 수준으로 처리하였다. 연구결과 토양에서 용 출되는 카드뮴과 납의 농도가 급격하게 감소하였는데 이는 $\mathrm{CaCO}_{3}$ 처리 후 증가된 토양의 $\mathrm{pH}$ 조건에서 중금속 용해도의 감소, 탄산염 형태로의 침전, 증대된 토양 $\mathrm{pH}$ 의존전하 $(\mathrm{pH}-$ dependent charge) 부위로의 중금속 흡착 증가에 기인한 결과라 고 하였다(Lee 등, 2004). Paulose 등(2007)은 20년 간의 하수 (sewage) 관개(irrigation)로 인해 구리, 니켈 $(\mathrm{Ni})$, 아연으로 오염 된 토양의 정화를 위해 $\mathrm{CaCO}_{3}$ 를 $5 \mathrm{wt} \%$ 수준으로 처리하였다. 연구결과 용출되는 중금속 농도가 감소하였는데 이는 $\mathrm{CaCO}_{3}$ 처리에 의해 토양 $\mathrm{pH}$ 가 상승하면서 증대된 토양 표면의 음전 하 부위로의 양이온성 중금속의 흡착 증가와 중금속 수산화물 로의 침전에 기인한다고 하였다(Paulose 등, 2007).

Brallier 등(1996)은 하수슬러지(sewage sludge)의 처리로 인해 카드뮴, 구리, 니켈, 아연으로 오염된 토양에 대하여 $\mathrm{Ca}(\mathrm{OH})_{2}$ 를 $8,15,22 \mathrm{Mg} / \mathrm{ha}$ 수준으로 처리하였다. 연구결과 $\mathrm{Ca}(\mathrm{OH})_{2}$ 처리 를 통해 토양의 $\mathrm{pH}$ 가 상승하면서 중금속의 용해도가 낮아져 용 해성 및 식물유효성(phytoavailable) 형태의 중금속 농도가 감소 하였고 실제로 작물에 흡수되는 중금속의 농도도 저감됨을 보 고하였다(Brallier 등, 1996). Castaldi 등(2005)은 폐광산 인근의 토양 내 납, 카드뮴, 아연의 정화를 위해 $\mathrm{Ca}(\mathrm{OH})_{2}$ 를 $0.05 \mathrm{wt} \%$ 수준으로 처리한 결과, 토양 내 생물유효성 납, 카드뮴, 아연의 농도가 감소하고 잔류성 분획의 농도가 증가하면서 재배식물로 전이되는 중금속의 농도도 감소함을 보고하였다. 이에 대해 Castaldi 등 $(2005)$ 는 $\mathrm{Ca}(\mathrm{OH})_{2}$ 의 처리 후 토양 $\mathrm{pH}$ 상승에 의한 중금속 침전물의 형성에 기인한 결과라고 하였다. Hong 등 (2009)은 아연 제련공장 인근 토양에 대한 카드뭄과 아연의 정 화를 위해 $\mathrm{Ca}(\mathrm{OH})_{2}$ 를 $2,4,8 \mathrm{Mg} / \mathrm{ha}$ 수준으로 처리하였다. 연 구결과 $\mathrm{Ca}(\mathrm{OH})_{2}$ 처리 후 토양 $\mathrm{pH}$ 가 상승하면서 토양의 양이 온 교환 용량(CEC, cation exchange capacity)이 증가하였고, 이에 기인하여 용출되는 카드뮴과 납의 농도가 감소하면서 재 배되는 작물로의 흡수도 저감됨을 보고하였다(Hong 등, 2009). Kostarelos 등(2006)은 $\mathrm{CaO}$ 를 크롬으로 오염된 토양에 처리하 였다. 연구결과 TCLP 용출성 크롬은 무처리구 대비 감소하는 것으로 나타났는데 이는 $\mathrm{CaO}$ 처리 후 토양 내에서 형성된 포 졸란 반응 산물 $(\mathrm{CSH}, \mathrm{CAH})$ 내에 크롬이 물리적 entrapment 에 의해 안정화된 것과 함께 높은 $\mathrm{pH}$ 조건에서 공극 표면으로 의 크롬 흡착 증대에 기인한 결과라고 하였다(Kostarelos 등, 2006).

알칼리물질 요약. 패각류, 난각류, 알칼리성 산업부산물 및 석 회와 같은 알칼리물질의 토양 처리에 의한 중금속의 안정화를 Table 1에 요약하여 나타내었다. 알칼리물질 처리 후 토양의 $\mathrm{pH}$ 가 상승하며 이 때 1) 토양 음전하 증대에 따른 양이온성 중금 속 흡착 증가, 2) 중금속 수산화물 및 3) 중금속 탄산염 형성, 4) 포졸란 반응 산물 $(\mathrm{CSH}, \mathrm{CAH})$ 형성에 의한 entrapment, 5) ettringite 형성 후 중금속 치환에 의한 안정화가 보고되었다. 한 
Table 1 Applications of various alkaline materials for stabilization of metal(loid)s in the soils

\begin{tabular}{|c|c|c|c|c|}
\hline Amendments & Target metals & Effects of amendments & Main mechanisms of metal stabilization & References \\
\hline \multicolumn{5}{|c|}{ Industrial by-products } \\
\hline Bottom ash & $\mathrm{Cd} / \mathrm{Cu} / \mathrm{Pb} / \mathrm{Zn}$ & Decrease in $0.5 \mathrm{M}-\mathrm{CaCl}_{2}$ extractable metals & Alkaline properties, sorption to particles and co-precipitation reactions & Lee et al., 2014 \\
\hline Cement kiln dust & As & Decrease in TCLP extractable As & $\begin{array}{l}\text { Formation of Ca-As precipitates such as i) Ca-As-O for } \mathrm{As}(\mathrm{III}) \text { and ii) } \\
\mathrm{NaCaAsO}_{4} \cdot 7.5 \mathrm{H}_{2} \mathrm{O} \text { for } \mathrm{As}(\mathrm{V})\end{array}$ & Moon et al., 2008 \\
\hline \multirow[t]{3}{*}{ Furnace slag } & $\mathrm{Cd} / \mathrm{Pb} / \mathrm{Zn}$ & $\begin{array}{l}\text { Decrease in water and } 0.1 \mathrm{M}-\mathrm{Ca}\left(\mathrm{NO}_{3}\right)_{2} \\
\text { extractable metals }\end{array}$ & $\begin{array}{l}\text { (1) Increased metal sorption to soil particles by increased soil } \mathrm{pH} \\
\text { (2) Fe and Al oxides in furnace slag introduce new sorptive surfaces } \\
\text { (specific sorption or chemisorption) }\end{array}$ & Lee et al., 2009 \\
\hline & As & Increase in $0.01 \mathrm{M}-\mathrm{CaCl}_{2}$ extractable As & Competition of As with $\mathrm{P}$ in furnace slag & Lim et al., 2010 \\
\hline & $\mathrm{Cd} / \mathrm{Cu} / \mathrm{Pb} / \mathrm{Zn}$ & Decrease in $0.5 \mathrm{M}-\mathrm{CaCl}_{2}$ extractable metals & Alkaline properties, sorption to particles and co-precipitation reactions & Lee et al., 2014 \\
\hline \multirow[t]{2}{*}{$\begin{array}{l}\text { Fly ash } \\
\text { (single treatment) }\end{array}$} & $\mathrm{Cr}$ & Decrease in TCLP extractable $\mathrm{Cr}$ & $\begin{array}{l}\text { Entrapped within a solid matrix formed by the pozzolanic reaction or } \\
\text { adsorbed on pore surface at high } \mathrm{pH}\end{array}$ & Kostarelos et al., 2006 \\
\hline & $\mathrm{Cu} / \mathrm{Pb}$ & Decrease in water extractable metals & Enhanced metal sorption due to increased amount of sorptive sites & Kumpiene et al., 2007 \\
\hline (quick lime mixture) & $\mathrm{Cr}$ & Decrease in TCLP extractable $\mathrm{Cr}$ & $\begin{array}{l}\text { Formation of pozzolanic compound } \\
\left(3 \mathrm{CaOAl}_{2} \mathrm{O}_{3} 0.5 \mathrm{CaCrO}_{4} 0.5 \mathrm{CaSO}_{4} \cdot \mathrm{nH}_{2} \mathrm{O}\right)\end{array}$ & $\begin{array}{l}\text { Dermatas and Moon, } \\
2006\end{array}$ \\
\hline $\begin{array}{l}\text { (calcined oyster } \\
\text { shell mixture) }\end{array}$ & $\mathrm{Cu} / \mathrm{Pb}$ & $\begin{array}{l}\text { Decrease in } 0.1 \mathrm{~N}-\mathrm{HCl} \text { and TCLP extractable } \\
\text { metals }\end{array}$ & Ettringite and pozzolanic reaction products ( $\mathrm{CAH}$ and $\mathrm{CSH})$ & Moon et al., 2013c \\
\hline $\begin{array}{l}\text { Porous hydrated } \\
\text { calcium silicate }\end{array}$ & $\mathrm{Cd}$ & Decrease in $\mathrm{Cd}$ in straw and brown rice & $\begin{array}{l}\text { Increased soil } \mathrm{pH} / \text { possibly silicate alters the forms of } \mathrm{Cd} \text { in soils or } \\
\text { enhances adsorption of } \mathrm{Cd} \text { by soils }\end{array}$ & $\begin{array}{l}\text { Zhao and Masaihiko, } \\
2007\end{array}$ \\
\hline \multirow[t]{5}{*}{ Red mud } & $\mathrm{As} / \mathrm{Cu}$ & $\begin{array}{l}\text { Decrease in } 1 \mathrm{M}-\mathrm{NH}_{4} \mathrm{NO}_{3} \text { extractable } \mathrm{Cu} \\
\text { Decrease in } 0.05 \mathrm{M}-\left(\mathrm{NH}_{4}\right)_{2} \mathrm{SO}_{4} \text { extractable As }\end{array}$ & $\begin{array}{l}\text { (1) Increased soil } \mathrm{pH} \text { after amendments } \\
\text { (2) Adsorption onto } \mathrm{Fe} \text { oxy-hydroxide after amendments (rich in } \mathrm{Fe} \text { ) }\end{array}$ & Lombi et al., 2004 \\
\hline & $\mathrm{Cu} / \mathrm{Cd} / \mathrm{Ni} / \mathrm{Pb} / \mathrm{Zn}$ & Decrease in $1 \mathrm{M}-\mathrm{NH}_{4} \mathrm{NO}_{3}$ extractable metals & $\begin{array}{l}\text { (1) Increased metal sorption due to increase in the net negative charge of } \\
\text { variably charged colloids in soils. } \\
\text { (2) Introduced new sorptive surfaces for specific or chemisorption after } \\
\text { addition of } \mathrm{Fe} \text { and } \mathrm{Al} \text { oxides in red mud }\end{array}$ & Gray et al., 2006 \\
\hline & $\mathrm{Cd} / \mathrm{Pb} / \mathrm{Zn}$ & $\begin{array}{l}\text { Decrease in bioavailable fractions and increase in } \\
\text { residual fraction }\end{array}$ & $\begin{array}{l}\text { (1) Metal precipitation } \\
\text { (2) Metal sorption by variably charged colloids such as organic matter and } \\
\text { Fe/Al oxides } \\
\text { (3) Increased adsorption capacity on cancrinite and hematite in red mud }\end{array}$ & Garau et al., 2007 \\
\hline & $\mathrm{Cd} / \mathrm{Pb} / \mathrm{Zn}$ & $\begin{array}{l}\text { Decrease in water extractable } \mathrm{Cd} \text { and } \mathrm{Zn} \text {, and } \\
0.1 \mathrm{M}-\mathrm{Ca}\left(\mathrm{NO}_{3}\right)_{2} \text { extractable metals } \\
\text { Increase in water extractable } \mathrm{Pb}\end{array}$ & $\begin{array}{l}\text { (1) Increased metal sorption to soil particles due to increase in soil } \mathrm{pH} \\
\text { (2) Fe and } \mathrm{Al} \text { oxides in red mud introduce new sorptive surfaces (specific } \\
\text { sorptions or chemisorptions) } \\
\text { (3) Increased Pb-the formation of soluble organo-complexes due to increase } \\
\text { in dissolved organic carbon (DOC). }\end{array}$ & Lee et al., 2009 \\
\hline & $\mathrm{Cd} / \mathrm{Cu} / \mathrm{Pb} / \mathrm{Zn}$ & Decrease in $0.5 \mathrm{M}-\mathrm{CaCl}_{2}$ extractable metals & Alkaline properties, sorption to particles and co-precipitation reactions & Lee et al., 2014 \\
\hline
\end{tabular}




\begin{tabular}{|c|c|c|c|c|}
\hline Amendments & Target metals & Effects of amendments & Main mechanisms of metal stabilization & References \\
\hline \multicolumn{5}{|l|}{ Limes } \\
\hline \multirow{4}{*}{$\begin{array}{l}\mathrm{CaCO}_{3} \\
\text { (Calcium } \\
\text { carbonate, } \\
\text { lime stone) }\end{array}$} & $\mathrm{Cd} / \mathrm{Pb} / \mathrm{Zn}$ & $\begin{array}{l}\text { Decrease in the concentrations of metals in } \\
\text { effluent from soil column }\end{array}$ & Formation of metal carbonates & $\begin{array}{l}\text { Basta and McGowen, } \\
2004\end{array}$ \\
\hline & $\mathrm{Cd} / \mathrm{Pb}$ & $\begin{array}{l}\text { Decrease in Cd in soil solution } \\
\text { Decrease in } 0.005 \mathrm{M} \text {-DTPA and } 0.05 \mathrm{M} \text {-EDTA } \\
\text { extractable Cd }\end{array}$ & $\begin{array}{l}\text { (1) Reduction of metal solubility } \\
\text { (2) Formation of metal carbonates by increased } \mathrm{pH} \\
\text { (3) Metal adsorption onto increased } \mathrm{pH} \text {-dependent charges of soil }\end{array}$ & Lee et al., 2004 \\
\hline & $\mathrm{Cu} / \mathrm{Ni} / \mathrm{Zn}$ & $\begin{array}{l}\text { Decrease in } 0.05 \mathrm{M} \text {-EDTA extractable } \mathrm{Cu}, \mathrm{Ni} \text { and } \\
\mathrm{Zn}\end{array}$ & $\begin{array}{l}\text { (1) Increased surface negative charge } \\
\text { (2) Formation of hydroxy species of metal cations that have a greater } \\
\text { affinity for adsorption sites } \\
\text { (3) Precipitation as metal hydroxides }\end{array}$ & Paulose et al., 2007 \\
\hline & $\mathrm{Cd} / \mathrm{Pb} / \mathrm{Zn}$ & $\begin{array}{l}\text { Decrease in water and } 0.1 \mathrm{M}-\mathrm{Ca}\left(\mathrm{NO}_{3}\right)_{2} \text { extractable } \\
\mathrm{Cd}, \mathrm{Pb} \text { and } \mathrm{Zn}\end{array}$ & Increased metal sorption to soil particles by increased soil $\mathrm{pH}$ & Lee et al., 2009 \\
\hline \multirow{4}{*}{$\begin{array}{l}\mathrm{Ca}(\mathrm{OH})_{2} \\
(\mathrm{Calcium} \\
\text { hydroxide, } \\
\text { slaked lime })\end{array}$} & $\mathrm{Cd} / \mathrm{Cu} / \mathrm{Ni} / \mathrm{Zn}$ & Decrease in soluble $\mathrm{Cd}, \mathrm{Cu}, \mathrm{Ni}$ and $\mathrm{Zn}$ & Decreased metal solubility by increased $\mathrm{pH}$ & Brallier et al., 1996 \\
\hline & $\mathrm{Cd} / \mathrm{Pb} / \mathrm{Zn}$ & $\begin{array}{l}\text { Decrease in bioavailable fractions of } \mathrm{Cd}, \mathrm{Pb} \text { and } \\
\mathrm{Zn}\end{array}$ & Metal precipitation & Castaldi et al., 2005 \\
\hline & $\mathrm{Cd} / \mathrm{Zn}$ & Decrease in $1 \mathrm{M}-\mathrm{NH}_{4} \mathrm{OAc}$ extractable $\mathrm{Cd}$ and $\mathrm{Zn}$ & Increase in soil CEC by increased $\mathrm{pH}$ & Hong et al., 2009 \\
\hline & $\mathrm{Cu} / \mathrm{Ni} / \mathrm{Pb} / \mathrm{Sb}$ & $\begin{array}{l}\text { Decrease in water and } 0.1 \mathrm{M}-\mathrm{NaNO}_{3} \text { extractable } \\
\mathrm{Cu}, \mathrm{Pb}, \mathrm{Ni} \text { and } \mathrm{Sb}\end{array}$ & NA & Conesa et al., 2010 \\
\hline $\begin{array}{l}\mathrm{CaO} \\
\text { (Calcium oxide, } \\
\text { quick lime) }\end{array}$ & $\mathrm{Cr}$ & Decrease in TCLP extractable $\mathrm{Cr}$ & $\begin{array}{l}\text { Entrapped within a solid matrix formed by the pozzolanic reaction or } \\
\text { adsorbed on pore surface at high } \mathrm{pH}\end{array}$ & Kostarelos et al., 2006 \\
\hline \multicolumn{5}{|c|}{ Shells and Egg shells } \\
\hline \multirow[t]{6}{*}{ Eggshell } & $\mathrm{Cd} / \mathrm{Pb}$ & $\begin{array}{l}\text { Decrease in } 0.01 \mathrm{M} \text { - and } 1 \mathrm{M}-\mathrm{CaCl}_{2}, 0.1 \mathrm{~N}-\mathrm{HCl} \text { and } \\
0.43 \mathrm{M} \mathrm{CH}_{3} \mathrm{COOH} \text { extractable } \mathrm{Cd} \text { and } \mathrm{Pb}\end{array}$ & $\begin{array}{l}\text { (1) Expanded negatively charged sites by increased soil pH } \\
\text { (2) Carbonate precipitation }\end{array}$ & Ok et al., 2011b \\
\hline & $\mathrm{Cu} / \mathrm{Pb}$ & $\begin{array}{l}\text { Increase in water extractable } \mathrm{Cu} \\
\text { Decrease in water extractable } \mathrm{Pb}\end{array}$ & $\begin{array}{l}\text { (1) } \mathrm{Cu} \text {-Formation of } \mathrm{Cu} \text {-DOC complexes } \\
\text { (2) } \mathrm{Pb} \text {-Formation of relatively insoluble } \mathrm{Pb} \text {-hydroxide }\end{array}$ & Ahmad et al., 2012c \\
\hline & $\mathrm{As} / \mathrm{Cd} / \mathrm{Pb}$ & $\begin{array}{l}\text { Decrease in } \mathrm{HCl} \text { and DTPA extractable As, Cd } \\
\text { and } \mathrm{Pb}\end{array}$ & $\begin{array}{l}\text { (1) } \mathrm{Cd} \text { and } \mathrm{Pb}-\mathrm{i} \text { ) Increased adsorption of cationic metal onto increased } \\
\text { negatively charged sites on soil particles and ii) the precipitation as metal } \\
\text { hydroxides or carbonates } \\
\text { (2) As-Formation of stable As-Ca complexes }\end{array}$ & $\begin{array}{l}\text { Abd El-Azeem et al., } \\
2013\end{array}$ \\
\hline & $\mathrm{Cd} / \mathrm{Pb}$ & Decrease in TCLP and $0.1 \mathrm{M}-\mathrm{HCl}$ metals & $\begin{array}{l}\text { (1) Increase of surface negative charge, } \\
\text { (2) Formation of hydroxyl species } \\
\text { (3) Precipitation of heavy metals as a form of hydroxides }\end{array}$ & Lee et al., 2013b \\
\hline & $\mathrm{Cd} / \mathrm{Pb}$ & Decrease in TCLP extractable metals & Increased cationic metal retention on soil surface by increased soil $\mathrm{pH}$ & Lim et al., 2013a \\
\hline & $\mathrm{As} / \mathrm{Cd} / \mathrm{Pb}$ & Decrease in $0.1 \mathrm{~N}-\mathrm{HCl}$ extractable $\mathrm{Cd}$ and $\mathrm{Pb}$ & Increase in soil $\mathrm{pH}$ & Lim et al., 2013b \\
\hline Calcined eggshell & $\mathrm{Pb}$ & Decrease in TCLP extractable $\mathrm{Pb}$ & $\begin{array}{l}\text { (1) Increase in negatively charged sites on soil particles by increased soil pH } \\
\text { (2) Ion exchange } \\
\text { (3) Precipitation of (hydr)oxide } \\
\text { (4) Co-precipitation with carbonates } \\
\text { (5) Entrapping into CSH (calcium-silicate-hydrate) }\end{array}$ & Ahmad et al., 2012a \\
\hline
\end{tabular}


Table 1 Continued

\begin{tabular}{|c|c|c|c|c|}
\hline Amendments & Target metals & Effects of amendments & Main mechanisms of metal stabilization & References \\
\hline \multirow[t]{3}{*}{ Mussel shell } & $\mathrm{As} / \mathrm{Cd} / \mathrm{Pb}$ & $\begin{array}{l}\text { Decrease in } \mathrm{HCl} \text { and DTPA extractable As, } \mathrm{Cd} \\
\text { and } \mathrm{Pb}\end{array}$ & $\begin{array}{l}\text { (1) } \mathrm{Cd} \text { and } \mathrm{Pb}-\mathrm{i}) \text { Increased adsorption of cationic metal onto increased } \\
\text { negatively charged sites on soil particles and ii) the precipitation as } \\
\text { metal hydroxides or carbonates } \\
\text { (2) As-Formation of stable As-Ca complexes }\end{array}$ & $\begin{array}{l}\text { Abd El-Azeem et al., } \\
2013\end{array}$ \\
\hline & $\mathrm{Pb}$ & Decrease in $\mathrm{Pb}$ bioavailability and bioaccessibility & Changes in soil $\mathrm{pH}$ after application of mussel shell & Ahmad et al., 2012b \\
\hline & $\mathrm{Cu} / \mathrm{Pb}$ & $\begin{array}{l}\text { Increase in water extractable } \mathrm{Cu} \\
\text { Decrease in water extractable } \mathrm{Pb}\end{array}$ & $\begin{array}{l}\text { (1) } \mathrm{Cu} \text {-Formation of } \mathrm{Cu} \text {-DOC complexes } \\
\text { (2) Pb-Formation of relatively insoluble } \mathrm{Pb} \text {-hydroxide }\end{array}$ & Ahmad et al., 2012c \\
\hline \multirow[t]{7}{*}{ Oyster shell } & As & Decrease in $1 \mathrm{~N}-\mathrm{HCl}$ extractable As & Formation of Ca-As species & Lim et al., 2009 \\
\hline & As & Decrease in $1 \mathrm{~N}-\mathrm{HCl}$ extractable As & Formation of Ca-As precipitation & Moon et al., 2009 \\
\hline & $\mathrm{Cd} / \mathrm{Pb}$ & Decrease in $0.1 \mathrm{~N}-\mathrm{HCl}$ extractable $\mathrm{Cd}$ and $\mathrm{Pb}$ & $\begin{array}{l}\text { (1) Formation of insoluble metal hydroxides in alkaline } \mathrm{pH} \\
\text { (2) Increase in the net negative soil surface charge }\end{array}$ & Ok et al., 2010 \\
\hline & $\mathrm{Cu} / \mathrm{Pb}$ & $\begin{array}{l}\text { Increase in water extractable } \mathrm{Cu} \\
\text { Decrease in water extractable } \mathrm{Pb}\end{array}$ & $\begin{array}{l}\text { (1) } \mathrm{Cu} \text {-Formation of } \mathrm{Cu}-\mathrm{DOC} \text { complexes } \\
\text { (2) } \mathrm{Pb} \text {-Formation of relatively insoluble } \mathrm{Pb} \text {-hydroxide }\end{array}$ & Ahmad et al., 2012c \\
\hline & $\mathrm{As} / \mathrm{Cd} / \mathrm{Pb}$ & $\begin{array}{l}\text { Decrease in } \mathrm{HCl} \text { and DTPA extractable As, } \mathrm{Cd} \\
\text { and } \mathrm{Pb}\end{array}$ & $\begin{array}{l}\text { (1) } \mathrm{Cd} \text { and } \mathrm{Pb}-\mathrm{i} \text { ) Increased adsorption of cationic metal onto increased } \\
\text { negatively charged sites on soil particles and ii) the precipitation as } \\
\text { metal hydroxides or carbonates } \\
\text { (2) As-Formation of stable As-Ca complexes }\end{array}$ & $\begin{array}{l}\text { Abd El-Azeem et al., } \\
2013\end{array}$ \\
\hline & $\mathrm{Sb}$ & Increase in water extractable $\mathrm{Sb}$ & Desorption from soil particles under alkaline conditions $(\mathrm{pH} \sim 8)$ & Ahmad et al., 2013 \\
\hline & $\mathrm{Cd} / \mathrm{Pb}$ & Decrease in TCLP extractable $\mathrm{Cd}$ and $\mathrm{Pb}$ & Increased metal retention on soil surface by increased soil $\mathrm{pH}$ & Lim et al., 2013a \\
\hline \multirow[t]{6}{*}{$\begin{array}{l}\text { Calcined oyster } \\
\text { shell }\end{array}$} & As & Decrease in $1 \mathrm{~N}-\mathrm{HCl}$ extractable As & $\begin{array}{l}\text { (1) Formation of Ca-As precipitation } \\
\text { (2) Pozzolanic reaction products such as CAHs and CSHs }\end{array}$ & Moon et al., 2009 \\
\hline & $\mathrm{Pb}$ & Decrease in $0.1 \mathrm{~N}-\mathrm{HCl}$ extractable $\mathrm{Pb}$ & $\mathrm{Pb}$ associated with $\mathrm{Al}$ and $\mathrm{Si}$ & Moon et al., 2010 \\
\hline & $\mathrm{Cd} / \mathrm{Pb}$ & Decrease in $0.1 \mathrm{~N}-\mathrm{HCl}$ extractable $\mathrm{Cd}$ and $\mathrm{Pb}$ & $\begin{array}{l}\text { (1) Formation of insoluble metal hydroxides in alkaline } \mathrm{pH} \\
\text { (2) Increase in the net negative soil surface charge }\end{array}$ & Ok et al., 2010 \\
\hline & As & Decrease in $1 \mathrm{~N}-\mathrm{HCl}$ extractable As & $\mathrm{AsO}_{4}{ }^{3-}$ substituted sulfate in ettringite (the torpedo-like Ca-As phase) & Moon et al., 2011 \\
\hline & $\mathrm{Sb}$ & Decrease in water extractable $\mathrm{Sb}$ & $\begin{array}{l}\text { Formation of ettringite and calcium antimonite }\left[\mathrm{Ca}\left(\mathrm{Sb}(\mathrm{OH})_{6}\right)_{2}\right] \\
\text { precipitation }\end{array}$ & Ahmad et al., 2013 \\
\hline & $\mathrm{As} / \mathrm{Cu} / \mathrm{Pb}$ & Decrease in $0.1 \mathrm{~N}-\mathrm{HCl}$ extractable $\mathrm{As}, \mathrm{Cu}$ and $\mathrm{Pb}$ & $\begin{array}{l}\text { Formation of Ca-As complex, Fe complex and pozzolanic reaction } \\
\text { products (CSH and CAH) }\end{array}$ & Lee et al., 2013a \\
\hline (cow bone mixture) & $\mathrm{Cu} / \mathrm{Pb}$ & Decrease in $0.1 \mathrm{~N}-\mathrm{HCl}$ extractable $\mathrm{Cu}$ and $\mathrm{Pb}$ & $\begin{array}{l}\text { Formation of ettringite, pozzolanic reaction products and pyromorphite-like } \\
\text { phases }\end{array}$ & Moon et al., 2013a \\
\hline
\end{tabular}


편, 일부의 경우 $\mathrm{pH}$ 상승 시 토양 내 $\mathrm{DOC}$ 와 중금속 결합에 의해 이동성이 증가하므로 이에 대한 주의가 필요하다.

\section{인 함유물질(P containing materials)}

인 함유물질은 알칼리물질과 함께 과거부터 토양 개량제로 사 용되는 대표적인 물질이다. 인 함유물질은 토양 내 중금속과 반 응하여 인산염을 형성하며, 특히 화학적으로 매우 안정한 불용 성의 납 화합물인 pyromorphite를 형성하면서 토양 중 중금속 을 안정화하는 것으로 알려져 있다(Kumpiene 등, 2008).

동물기원물질(Animal source materials). 동물로부터 기원한 인 함유물질 폐자원 개량제로는 소뼈(cow bone), 닭뼈(chicken bone)와 같은 동물의 뼈가 주로 사용되었다. 소뼈와 닭뼈 같은 동물뼈에는 인이 다량으로 함유되어 있으며(Kim 등, 2009), 일 반적인 인 함유물질의 중금속 안정화와 동일하게 토양 내 중금 속을 안정화할 수 있다. 이 외에도 축분(livestock manure) 등이 사용되고 있으며, 대표적인 연구결과들은 다음과 같다(Table 2). Chen 등(2006)은 제련업 지역 인근 오염토양 내 납의 정화를 위해 탄화골분(bone char)을 처리하였다. 연구결과 교환성 납은 탄화골분 처리를 통해 감소하였으며, 안정한 형태의 잔류성 납 은 무처리구(39.2\%)와 비교할 때 급격히 증가 $(82.7-82.8 \%)$ 하였 다. 이는 $\mathrm{XRD}$ 분석결과 수산화인회석[hydroxyapatite, $\mathrm{Ca}_{10}$ $\left.\left(\mathrm{PO}_{4}\right)_{6}(\mathrm{OH})_{2}\right]$ 이 주성분인 탄화골분의 처리를 통해 화학적으로 안정한 형태인 lead phosphate $\left(\mathrm{Pb}_{2} \mathrm{P}_{4} \mathrm{O}_{12}\right)$ 및 lead hydroxyapatitelike minerals $\left[\mathrm{Pb}_{10}\left(\mathrm{PO}_{4}\right)_{6}(\mathrm{OH})_{2}\right]$ 의 형성에 기인한 결과라고 하였 다(Chen 등, 2006).

Ahmad 등 $(2012 \mathrm{~b})$ 은 사격장 토양 내 납의 안정화를 위해 소 뼈 분말을 $5 \mathrm{wt} \%$ 수준으로 처리하였다. 항온배양 7 일 후 물 (water)과 $1 \mathrm{M}-\mathrm{NH}_{4} \mathrm{NO}_{3}$ 용출성 납과 PBET (physiologically based extraction test)를 통한 생물유효성 납의 농도를 평가하였다. 연 구결과 소뼈 처리를 통해 용출되는 납의 농도가 상당량 감소하 였는데, 이는 소뼈 처리 후 토양 $\mathrm{pH}$ 의 상승에 의한 중금속 수 산화물 침전과, 중금속-인산염(metal phosphates) 형성에 기인한 결과라고 하였다(Ahmad 등, 2012b).

$\operatorname{Lim}$ 등(2013b)은 카드뮴, 납, 비소로 오염된 토양에 닭뼈와 소성한 닭뼈를 처리하였다. 연구결과 $0.1 \mathrm{M}-\mathrm{HCl}$ 용출성 카드뮴 과 납의 농도는 감소하였는데 이는 $\mathrm{pH}$ 상승에 의한 토양 교질 로의 중금속 흡착 증대 및 탄산염, 수산화물로의 침전에 기인 하며, 일부는 닭뼈에 함유된 수산화인회석에 의해 부분적으로 $\mathrm{Cd}_{3}\left(\mathrm{PO}_{4}\right)_{2}$ 와 같은 카드뮴-인산염의 형성 및 pyromorphite와 같 은 납-인산염의 형성에 의한 용출농도 감소임을 보고하였다. 그 러나 닭벼에 함유된 인과 토양 내 비소의 경합으로 인해 토양 으로부터의 비소 용출농도가 증가하는 것으로 나타나 이에 대 한 주의가 필요하다고 하였다(Lim 등, 2013b).

일반물질(General source materials). 인 함유물질은 과거부터 토양 내 중금속, 특히 납의 안정화에 널리 사용되어 왔다. 주로 인광석(PR) 및 인산용액(PA, phosphoric acid)이 사용되며 중금 속-인 화합물의 형성을 통해 토양 내 중금속을 안정화하는 것 으로 보고되고 있다. 이에 대한 대표적인 연구결과들은 다음과 같다(Table 2).

Basta와 McGowen(2004)은 금속 제련 공장 인근 오염토양에 $\mathrm{PR}$ 과 $\left(\mathrm{NH}_{4}\right)_{2} \mathrm{HPO}_{4}$ (DAP, diammonium phosphate)를 처리한 후 컬럼용출실험을 실시하였다. 연구결과 PR과 DAP가 처리된
토양 컬럼의 용출액 내 카드뮴은 각각 $53,94.6 \%$ 감소, 납은 각각 $99.9,98.9 \%$ 감소, 아연은 각각 $24,95.8 \%$ 감소하는 것으 로 나타났다. 이는 광물흡착 및 침전, pyromorphite형태와 중금 속-인산염 형성에 기인한 결과임을 보고하였다(Basta와 McGowen, 2004). 이와 유사하게 Scheckel과 Ryan(2004)은 납 제련소 $\left(\mathrm{Pb}\right.$ smelter) 인근 토양에 $\mathrm{Ca}\left(\mathrm{H}_{2} \mathrm{PO}_{4}\right) \cdot \mathrm{H}_{2} \mathrm{O}$ (TSP, triple super phosphate), $\mathrm{PR}, \mathrm{PA}$ 을 처리한 후 토양 내 납 화학종을 EXAFSLCF (extended X-ray absorption fine structure-linear combination fitting)로 평가하였다. 연구결과 인 함유물질 3종의 처리는 토양 내 납을 화학적으로 매우 안정한 형태인 pyromorphite로 변환 하였으며, 이는 처리구별로 각각 $29,33,45 \%$ 까지 존재함을 보 고하였다(Scheckel과 Ryan, 2004). Cao 등(2009)은 오염토양 내 납, 구리, 아연의 안정화를 위하여 $\mathrm{PR}$ 과 $\mathrm{PA}$ 를 토양에 처리 하였다. 연구결과 $\mathrm{PR}$ 과 $\mathrm{PA}$ 의 처리는 토양 내 납을 안정화하였 는데 이는 pyromorphite와 같은 불용성의 납-인산염 형성에 기 인한 결과라고 보고하였다. 한편, $\mathrm{PA}$ 처리에 의한 토양의 $\mathrm{pH}$ 하강은 결과적으로 구리와 아연의 이동성(mobility)을 증대시켰 으며, calcium oxide $(\mathrm{CaO})$ 의 처리 후 토양이 다시 중화할 때 안정화되는 것으로 나타났다. Cao 등(2009)은 이 연구를 통해 단일 개량제로는 여러 가지 중금속으로 복합 오염된 지역의 정 화가 적절하지 않음을 강조하였다. 이와 함께 Fayiga와 $\mathrm{Ma}(2006)$ 는 비소, 카드뮴, 납, 아연으로 오염된 토양에 PR을 $50 \mathrm{mg} / \mathrm{kg}$ 수준으로 처리하는 연구를 실시하였다. 연구결과 PR 의 처리는 고축적종(hyperaccumulator) 식물에 의한 비소의 흡 수를 증가시킴과 동시에 납과 카드뮴의 식물흡수를 감소시키는 것으로 나타났다. 이는 비소와 화학적으로 유사한 성질을 지니 는 인의 처리가 토양으로부터의 비소방출을 증대시킨 것에 기 인한 결과이며, 반대로 $\mathrm{PR}$ 이 중금속을 안정화시킨 것에 기인한 결과라고 하였다(Fayiga와 Ma, 2006). Fayiga와 $\mathrm{Ma}$ (2006)은 이 연구를 통해 적절한 수준의 PR 처리는 비소 및 타 중금속으로 오염된 토양의 식물정화(phytoremediation)에 효과적임을 보고하 였다. 또한 Conesa 등(2010)은 사격장 토양 내 구리, 납, 니켈, 안티몬의 안정화를 위해 $\mathrm{KH}_{2} \mathrm{PO}_{4}$ 를 처리하였다. 연구결과 수용 성 구리, 납, 니켈은 증가하지 않았으나 안티몬의 경우 증가하 였는데 이는 인산이 토양의 결합부위에 대해서 antimonite 등과 경합하기 때문임을 보고하였다. 그러므로 여러 가지 중금속으로 오염된 경우에는 안정화제 처리에 주의가 필요하다고 하였다 (Conesa 등, 2010).

한편, Baker 등(2012)은 납/아연 제련소 토양에 대한 납 안정 화를 위해 인 함유물질을 처리하였다. 연구결과 입상형태의 PR 과 TSP 처리구에서 각각 scholzite $\left[\mathrm{CaZn} 2\left(\mathrm{PO}_{4}\right)_{2} \cdot 2 \mathrm{H}_{2} \mathrm{O}\right]$ 와 hopeite $\left[\mathrm{Zn}_{3}\left(\mathrm{PO}_{4}\right)_{2} \cdot 4 \mathrm{H}_{2} \mathrm{O}\right]$ 이 형성됨을 확인하였다. 액상형태의 $\mathrm{PA}$ 는 토 양 처리 시에 $\mathrm{pH}$ 를 하강시켜 아연을 상대적으로 용해성인 $\mathrm{Zn}-$ sulfate, $\mathrm{Zn}$ hydroxide[ $\left.\mathrm{Zn}(\mathrm{OH})_{2}\right]$ 를 형성하게 한다고 하였다. 아 연은 납 오염토양에서 주로 존재하는 중금속이므로 납의 안정 화를 위한 인 함유물질의 처리 시 PA보다는 PR이 아연의 용출 저감에 효과적이며, 인 함유물질의 처리 후에는 토양에 대한 지 속적인 모니터링을 통해 처리된 인의 수계 유입에 대한 주의가 필요하다고 하였다. 이와 함께 인 함유물질의 처리는 상대적으 로 불용성의 아연 $\left(\mathrm{ZnFe}_{2} \mathrm{O}_{4}, \mathrm{ZnAl}_{2} \mathrm{O}_{4}\right)$ 을 용해성의 아연-인산염 으로 변환하면서 아연의 용출을 더욱 용이하게 할 가능성이 있 어 이에 대한 연구가 필요하다고 하였다(Baker 등, 2012).

인 함유물질 요약. 동물의 뼈, 인광석, 인산용액과 같은 인 함 유물질의 토양 처리에 의한 중금속 안정화를 Table 2에 요약하 
Table 2 Applications of various P-containing materials for stabilization of metal(loid)s in the soils

\begin{tabular}{|c|c|c|c|c|}
\hline Amendments & Target metals & Effects of amendments & Main mechanisms of metal stabilization & References \\
\hline \multicolumn{5}{|l|}{ Animal sources } \\
\hline Bone char & $\mathrm{Pb}$ & Decrease in exchangeable $\mathrm{Pb}$ & $\begin{array}{l}\text { Formation of } \mathrm{Pb} \text {-phosphates such as lead phosphate }\left(\mathrm{Pb}_{2} \mathrm{P}_{4} \mathrm{O}_{12}\right) \text { and lead } \\
\text { hydroxyapatite-like minerals }\left[\mathrm{Pb}_{10}\left(\mathrm{PO}_{4}\right)_{6}(\mathrm{OH})_{2}\right]\end{array}$ & Chen et al., 2006 \\
\hline $\begin{array}{l}\text { Chicken bone and } \\
\text { calcined chicken } \\
\text { bone }\end{array}$ & $\mathrm{As} / \mathrm{Cd} / \mathrm{Pb}$ & $\begin{array}{l}\text { Increase in } 1 \mathrm{~N}-\mathrm{HCl} \text { extractable } \mathrm{As} \\
\text { Decrease in } 0.1 \mathrm{~N}-\mathrm{HCl} \text { extractable } \mathrm{Cd} \text { and } \mathrm{Pb}\end{array}$ & $\begin{array}{l}\text { (1) Increased As-Competition of phosphate with As for surface binding } \\
\text { sites on the solids } \\
\text { (2) Decreased } \mathrm{Cd} \text { and } \mathrm{Pb} \text {-the rise in soil } \mathrm{pH}\end{array}$ & Lim et al., 2013b \\
\hline \multirow[t]{2}{*}{ Cow bone } & $\mathrm{Pb}$ & Decrease in $\mathrm{Pb}$ bioavailability and bioaccessibility & $\begin{array}{l}\text { Changes in soil pH after application of cow bone and the formation of metal } \\
\text { phosphate }\end{array}$ & Ahmad et al., 2012b \\
\hline & $\mathrm{Pb} / \mathrm{Sb}$ & $\begin{array}{l}\text { Decrease in } 1 \mathrm{M}-\mathrm{NH}_{4} \mathrm{NO}_{3} \text { extractable } \mathrm{Pb} \\
\text { Increase in } 1 \mathrm{M}-\mathrm{NH}_{4} \mathrm{NO}_{3} \text { extractable } \mathrm{Sb}\end{array}$ & $\begin{array}{l}\text { (1) Decreased } \mathrm{Pb}-\mathrm{i} \text { ) Increased soil } \mathrm{pH} \text { and ii) } \mathrm{Pb} \text { sorbed on kaolinite in cow } \\
\text { bone amended soils } \\
\text { (2) Increased } \mathrm{Sb} \text {-Increased } \mathrm{Sb} \text { solubility and desorption from soil particles }\end{array}$ & Ahmad et al., 2014a \\
\hline $\begin{array}{l}\text { (calcined oyster } \\
\text { shell mixture) }\end{array}$ & $\mathrm{Cu} / \mathrm{Pb}$ & Decrease in $0.1 \mathrm{~N}-\mathrm{HCl}$ extractable $\mathrm{Cu}$ and $\mathrm{Pb}$ & $\begin{array}{l}\text { Formation of ettringite, pozzolanic reaction products and pyromorphite-like } \\
\text { phases }\end{array}$ & Moon et al., 2013a \\
\hline $\begin{array}{l}\text { Dairy manure } \\
\text { derived biochar }\end{array}$ & $\mathrm{Pb}$ & $\begin{array}{l}\text { Decrease in } 0.01 \mathrm{M} \mathrm{CaCl}_{2} \text { and TCLP extractable } \\
\mathrm{Pb}\end{array}$ & Formation of hydroxypyromorphite $\left[\mathrm{Pb}_{5}\left(\mathrm{PO}_{4}\right)_{3}(\mathrm{OH})\right]$ & Cao et al., 2011 \\
\hline $\begin{array}{l}\text { Incinerated poultry } \\
\text { waste }\end{array}$ & $\mathrm{Pb}$ & Decrease in TCLP extractable $\mathrm{Pb}$ & Formation of less soluble $\mathrm{Pb}$ species such as pyromorphite & Hashimoto et al., 2009 \\
\hline
\end{tabular}


Table 2 Continued

\begin{tabular}{|c|c|c|c|c|}
\hline Amendments & Target metals & Effects of amendments & Main mechanisms of metal stabilization & References \\
\hline \multicolumn{5}{|l|}{ General sources } \\
\hline $\begin{array}{l}\text { Ammonium } \\
\text { phosphate }\end{array}$ & $\mathrm{Pb} / \mathrm{Zn}$ & NA & NA & Baker et al., 2012 \\
\hline $\begin{array}{l}\text { Diammonium } \\
\text { phosphate }\end{array}$ & $\mathrm{Cd} / \mathrm{Pb} / \mathrm{Zn}$ & $\begin{array}{l}\text { Decrease in concentrations of metals in effluent } \\
\text { from soil column }\end{array}$ & $\begin{array}{l}\text { Formation of metal phosphates precipitates or minerals (Lead } \\
\text { hydroxypyromorphite) }\end{array}$ & $\begin{array}{l}\text { Basta and McGowen, } \\
2004\end{array}$ \\
\hline $\begin{array}{l}\text { Monoammonium } \\
\text { phosphate }\end{array}$ & $\mathrm{Pb} / \mathrm{Zn}$ & NA & NA & Baker et al., 2012 \\
\hline $\begin{array}{l}\text { Phosphate } \\
\left(\mathrm{KH}_{2} \mathrm{PO}_{4}\right)\end{array}$ & $\mathrm{Cu} / \mathrm{Ni} / \mathrm{Pb} / \mathrm{Sb}$ & Increase in water extractable $\mathrm{Sb}$ & $\begin{array}{l}\text { Competition between added phosphate with antimonite for same binding } \\
\text { sites }\end{array}$ & Conesa et al., 2010 \\
\hline \multirow[t]{5}{*}{ Phosphate rock } & $\mathrm{Cd} / \mathrm{Pb} / \mathrm{Zn}$ & $\begin{array}{l}\text { Decrease in concentrations of metals in effluent } \\
\text { from soil column }\end{array}$ & Mineral sorption and precipitation of metals in solution & $\begin{array}{l}\text { Basta and McGowen, } \\
2004\end{array}$ \\
\hline & $\mathrm{Cu} / \mathrm{Pb} / \mathrm{Zn}$ & Decrease in water soluble and bioaccessible $\mathrm{Pb}$ & $\begin{array}{l}\text { Formation of insoluble } \mathrm{Pb} \text { phosphate minerals such as pyromorphite-like } \\
\text { mineral }\end{array}$ & Cao et al., 2009 \\
\hline & $\mathrm{As} / \mathrm{Cd} / \mathrm{Pb} / \mathrm{Zn}$ & Increase in As uptake by hyperaccumulator & $\begin{array}{l}\text { Increase in As release from soil due to similar chemical properties of P in } \\
\text { phosphate rock with As }\end{array}$ & Fayiga and Ma, 2006 \\
\hline & $\mathrm{Pb} / \mathrm{Zn}$ & NA & NA & Baker et al., 2012 \\
\hline & $\mathrm{Pb}$ & NA & Formation of pyromorphite & $\begin{array}{l}\text { Scheckel and Ryan, } \\
2004\end{array}$ \\
\hline \multirow[t]{3}{*}{ Phosphoric acid } & $\mathrm{Cu} / \mathrm{Pb} / \mathrm{Zn}$ & $\begin{array}{l}\text { Decrease in water soluble and bioaccessible } \mathrm{Pb} \\
\text { Increase in bioaccessible } \mathrm{Cu} \text { and } \mathrm{Zn}\end{array}$ & $\begin{array}{l}\text { (1) Decrease-Formation of insoluble } \mathrm{Pb} \text { phosphate minerals such as } \\
\text { pyromorphite } \\
\text { (2) Increase-Decreased soil } \mathrm{pH} \text { after application of phosphoric acid }\end{array}$ & Cao et al., 2009 \\
\hline & $\mathrm{Pb} / \mathrm{Zn}$ & Increase in $\mathrm{Zn}$ solubility & Increase-Decreased soil $\mathrm{pH}$ after application of phosphoric acid & Baker et al., 2012 \\
\hline & $\mathrm{Pb}$ & NA & Formation of pyromorphite & $\begin{array}{l}\text { Scheckel and Ryan, } \\
2004\end{array}$ \\
\hline $\begin{array}{l}\text { Single super } \\
\text { phosphate }\end{array}$ & $\mathrm{Cu} / \mathrm{Ni} / \mathrm{Zn}$ & Decrease in $\mathrm{Cu}$ content in lettuce & $\begin{array}{l}\text { Specifically sorbed anion, such as phosphate, forms complexes with the soil } \\
\text { surface so that cations are adsorbed onto the adsorbed anions }\end{array}$ & Paulose et al., 2007 \\
\hline \multirow[t]{2}{*}{$\begin{array}{l}\text { Triple super } \\
\text { phosphate }\end{array}$} & $\mathrm{Pb}$ & NA & Formation of pyromorphite & $\begin{array}{l}\text { Scheckel and Ryan, } \\
2004\end{array}$ \\
\hline & $\mathrm{Pb} / \mathrm{Zn}$ & NA & NA & Baker et al., 2012 \\
\hline
\end{tabular}


여 나타내었다. 인 함유물질은 토양 처리 후 중금속과 반응하 여 1) 다양한 인산염 및 2) 불용성의 pyromorphite를 형성하여 중금속을 안정화하는 것으로 보고되었다. 그러나 인 함유물질의 토양 처리는 인과 유사한 화학적 동태를 보이는 음이온성 원소 인 비소, 셀레늄, 안티몬 및 텅스텐의 용출능을 증대시키며 과 도한 사용량 등으로 인해 인근 수계에 유입되어 부영양화 (eutrophication) 유발물질로 작용할 수 있으므로 처리 전 토양 에 대한 조사와 모니터링이 반드시 필요하다(Chrysochoou 등, 2007).

\section{유기성 물질(Organic materials)}

축분과 같은 유기성 폐자원은 과거부터 토양에 대한 필수양분 의 공급원으로 과거부터 널리 사용되어 왔다. 특히 최근에는 대 형화된 가축사육 및 $\mathrm{MSW}$ 등의 급격한 증가로 인해 유기성 폐 자원이 오염부지의 정화용 물질로 주목을 받고 있다(Park 등, 2011b). 특히, 유기성 폐자원으로부터 생산한 바이오차의 토양 처리는 1) 바이오차 표면 흡착, 2) $\mathrm{pH}$ 상승에 따른 토양 흡착 증대, 3) 침전물 형성 등을 통해 중금속을 안정화할 수 있으며 (Beesley와 Marmiroli, 2011; Park 등, 2011a; Khan 등, 2013; Moon 등, 2013b), 퇴비(compost) 및 가축분(manure)과 같은 바 이오 고형물(biosolids)의 토양 처리는 1) 토양 표면의 중금속 흡착 증대 및 2) 유기물, 중금속 간의 안정한 복합체 형성에 의 해 중금속을 안정화하는 것으로 보고되고 있다(Castaldi 등, 2005; Kumpiene 등, 2007).

바이오차(Biochars). 바이오차는 산소가 제한된 조건에서 부산 물 바이오매스(biomass)를 고온으로 열분해(pyrolysis)하였을 때 생성되는 고형물로 최근 수질 및 토양 내 유-무기 오염물질 의 정화에서 활용 빈도가 점차 높아지고 있는 물질이다(Ahmad 등, 2014b; Lim 등, 2014). 이에 대한 대표적인 연구결과들은 다음과 같다(Table 3).

Moon 등(2013b)은 사격장 오염토양 내 납의 안정화를 위해 콩줄기(soybean stover)를 원료로 생산한 바이오차를 1-20 wt \% 수준으로 처리하였다. 연구결과 TCLP 용출성 납은 바이오차 20 $\mathrm{wt} \%$ 처리구에서 무처리구 대비 $90 \%$ 이상 감소하였다. 이는 바 이오차의 처리 후 증가된 토양 $\mathrm{pH}$ 조건에서 $\mathrm{CAH}$ 및 $\mathrm{CSH}$ 와 같은 포졸란 반응 산물의 형성 및 바이오차에 함유된 인과 납 의 반응에 의한 chloropyromorphite $\left[\mathrm{Pb}_{5}\left(\mathrm{PO}_{4}\right)_{3} \mathrm{Cl}\right]$ 및 납-인산염 형성에 기인한다고 하였다(Moon 등, 2013b). Cao 등(2011)은 축분(dairy manure)으로 생산한 바이오차를 오염토양 내 납의 안정화를 위해 $2.5,5 \mathrm{wt} \%$ 수준으로 처리하였다. 연구결과 바이 오차 처리구에서 $0.01 \mathrm{M} \mathrm{CaCl}$ 용출성 납과 TCLP 용출성 납이 감소하였는데, 이는 상대적으로 높은 용해도를 가지는 cerussite $\left(\mathrm{PbCO}_{3}, K_{s p}=\sim 10^{-12}\right)$ 와 hydrocerussite $\left[\mathrm{Pb}_{3}\left(\mathrm{CO}_{3}\right)_{2}(\mathrm{OH})_{2}, K_{s p}=\sim 10^{-}\right.$ ${ }^{18}$ 가 인 함유물질인 축분 바이오차의 처리 후 상대적으로 매우 안정한 형태로 낮은 용해도를 보유한 hydroxypyromorphite $\left[\mathrm{Pb}_{5}\left(\mathrm{PO}_{4}\right)_{3}(\mathrm{OH}), K_{s p}=\sim 10^{-78}\right]$ 로 변환된 것에 기인한 결과임을 $\mathrm{XRD}$ 분석결과를 통해 제시하였다(Cao 등, 2011). 한편, 이 연 구에서 축분 바이오차는 납과 함께 유기오염물질인 atrazine의 동시 안정화에도 효과적인 것으로 나타났다(Cao 등, 2011).

Ahmad 등(2014a)은 사격장 오염토양 내 납과 안티몬의 안정 화를 위해 오크나무(oak wood)를 원료로 생산한 바이오차를 5 $\mathrm{wt} \%$ 수준으로 처리하였다. 연구결과 바이오차 처리구에서 교환
성 납의 농도는 $84 \%$ 까지 감소하였는데 이는 $\mathrm{pH}$ 상승효과와 함 께, SEM-EDX 및 EXAFS 분석을 통해 카올리나이트(kaolinite) 로의 흡착 등에 의한 결과라고 하였다. 안티몬은 바이오차 처 리구에서 증가하였는데 이는 바이오차 처리를 통해 증가된 $\mathrm{pH}$ 조건에서 토양 입자로부터의 탈착 및 증대된 안티몬의 용해도 에 기인한 결과라고 하였다(Ahmad 등, 2014a). 이와 함께 Uchimiya 등(2010)은 가금류 폐기물(broiler litter)로 생산한 바 이오차를 토양에 처리한 후 합성 강우(synthetic rain water, $\mathrm{pH}$ 4.5 )를 사용하여 24 시간 중금속 용출시험을 실시하였다. 연구결 과 납, 니켈, 카드뮴의 농도는 바이오차 처리구에서 무처리구 대비 감소하였는데, 이는 바이오차 처리 후 토양의 $\mathrm{pH}$ 상승에 의한 토양의 중금속 보유능 증대, 침전물 형성 등에 기인한다 고 하였다(Uchimiya 등, 2010).

Beesley와 Marmiroli(2011)은 견목재(hardwoods)들로 생산한 바이오차와 오염토양이 혼합 충진된 컬럼에 대한 용출액 분석 을 실시하였다. 연구결과에서 바이오차에 의한 흡착을 통해 토 양으로부터 용출되는 카드뮴과 아연이 감소함을 보고하였으며, 이는 바이오차 표면으로의 흡착에 의한 감소효과라고 하였다 (Beesley와 Marmiroli, 2011). Jiang 등(2012)은 산성화된 토양 에 볏짚(rice straw) 유래 바이오차를 처리한 후 토양에서의 중 금속 안정화 연구를 실시하였다. 연구결과 구리, 납, 카드뮴의 $0.11 \mathrm{M}$-acetic acid 용출성 중금속이 감소하였다. 이는 바이오차 처리 후 $\mathrm{pH}$ 상승으로 인한 중금속 침전물의 형성, 토양 표면으 로의 흡착 증대 및 바이오차의 산소 함유 관능기 $(-\mathrm{COOH},-\mathrm{OH})$ 와 구리 및 납의 안정한 복합체 형성과 같은 특이적 흡착의 증 대 등에 의한 감소효과라고 하였다(Jiang 등, 2012). 또한 Park 등(2011a)은 중금속으로 오염된 토양에 계분(chicken manure) 및 green waste로 생산한 바이오차를 $5 \mathrm{wt} \%$ 수준으로 처리하여 카드뮴, 구리, 납의 안정화 효과를 평가하였다. 연구결과 $1 \mathrm{M}-$ $\mathrm{NH}_{4} \mathrm{NO}_{3}$ 용출성 카드뮴과 납의 농도는 급격하게 감소하였으며 구리의 경우 감소효율이 상대적으로 낮았다. 이와 함께 연속추 출을 통한 중금속 분획화 결과, 연구대상 중금속의 교환성 분 획의 농도가 바이오차 처리에 의해 급격하게 감소함을 보고하 였는데, 이는 계분 및 green waste 바이오차 처리에 의한 중금 속 수산화물 및 탄산염의 형성, 인산염 침전에 의한 것과 바이 오차가 보유한 관능기 $(-\mathrm{OH},-\mathrm{COOH}, \mathrm{C}=\mathrm{N})$ 로의 흡착 등에 의 한 결과라고 하였다(Park 등, 2011a).

한편, Khan 등(2013)은 하수슬러지로 생산한 바이오차를 토 양에 처리하여 생물유효성 중금속 $(\mathrm{As}, \mathrm{Cd}, \mathrm{Cr}, \mathrm{Co}, \mathrm{Cu}, \mathrm{Ni}$, $\mathrm{Pb}, \mathrm{Zn})$ 의 저감 효율을 평가하였다. 연구결과 생물유효성 비소, 코발트(Co), 크롬, 니켈, 납은 $\mathrm{pH}$ 상승에 따른 토양으로의 흡착 증진 및 침전물 형성에 의해 감소하였으며, 구리, 아연, 카드뮴 은 하수슬러지 바이오차에 함유된 다량의 구리, 아연, 카드뮴의 영향으로 증가함을 보고하였다(Khan 등, 2013).

바이오 고형물(Biosolids). 현재 토양 내 중금속의 안정화를 위 해 사용되고 있는 바이오 고형물은 주로 퇴비(compost), 가축분 (manure) 등이 있으며 이에 대한 대표적인 연구결과들은 다음 과 같다(Table 3).

Castaldi 등(2005)은 광미로 인해 오염된 토양 내 중금속 $(\mathrm{Pb}$, $\mathrm{Cd}, \mathrm{Zn}$ )의 안정화를 위해 퇴비(olive husk $50 \%$, sewage sludge $25 \%$, vegetal waste $25 \%$ )를 $10 \mathrm{wt} \%$ 수준으로 처리하였다. 연 구결과 토양 내 납, 카드뮴, 아연의 잔류성 분획이 증가하고 생 물유효성 분획의 농도가 감소하였는데 이는 퇴비가 처리된 후 토양 표면으로의 중금속 흡착 증대에 의한 결과라고 하였다 
Table 3 Applications of various organic materials for stabilization of metal(loid)s in the soils

\begin{tabular}{|c|c|c|c|}
\hline Amendments & Target metals & Effects of amendments & Main mechanisms of metal stabilization \\
\hline \multicolumn{4}{|l|}{ Biochars } \\
\hline $\begin{array}{l}\text { Biochar } \\
\text { (broiler litter) }\end{array}$ & $\mathrm{Cd} / \mathrm{Ni} / \mathrm{Pb}$ & Decrease in metals extracted by synthetic rain water & $\begin{array}{l}\text { (1) Metal precipitations } \\
\text { (2) Sorption } \\
\text { (3) Specific metal-ligand complexation involving surface functional group } \\
\text { of biochar }\end{array}$ \\
\hline (chicken manure) & $\mathrm{Cu} / \mathrm{Cd} / \mathrm{Pb}$ & Decrease in $1 \mathrm{M}-\mathrm{NH}_{4} \mathrm{NO}_{3}$ extractable $\mathrm{Cd}$ and $\mathrm{Pb}$ & Formation of metal (hydr)oxide, carbonate or phosphate precipitates \\
\hline
\end{tabular}

$\begin{array}{ll}\text { (chicken manure) } & \mathrm{Cu} / \mathrm{Cd} / \mathrm{Pb} \\ \text { (dairy manure) } & \mathrm{Pb} \\ \text { (green waste) } & \mathrm{Cu} / \mathrm{Cd} / \mathrm{Pb} \\ \text { (hardwoods) } & \mathrm{Cd} / \mathrm{Zn}\end{array}$

$\mathrm{Cd} / \mathrm{Zn}$

(oak wood)

\begin{tabular}{|c|c|}
\hline & $\mathrm{Pb} / \mathrm{Sb}$ \\
\hline $\begin{array}{l}\text { (ochard prune } \\
\text { residues) }\end{array}$ & $\begin{array}{l}\mathrm{Cd} / \mathrm{Cr} / \mathrm{Cu} / \mathrm{Ni} / \\
\mathrm{Ti} / \mathrm{Zn}\end{array}$ \\
\hline (rice straw) & $\mathrm{Cd} / \mathrm{Cu} / \mathrm{Pb}$ \\
\hline (soybean stover) & $\mathrm{Pb}$ \\
\hline (sewage sludge) & $\begin{array}{l}\mathrm{As} / \mathrm{Cd} / \mathrm{Co} / \mathrm{Cr} / \\
\mathrm{Ni} / \mathrm{Pb} / \mathrm{Zn}\end{array}$ \\
\hline \multicolumn{2}{|l|}{ Biosolids } \\
\hline $\begin{array}{l}\text { Compost (derived } \\
\text { green waste, catering, } \\
\text { paper, municipal } \\
\text { solid and peat) }\end{array}$ & $\mathrm{As} / \mathrm{Cu} / \mathrm{Pb} / \mathrm{Zn}$ \\
\hline $\begin{array}{l}\text { (derived olive husk, } \\
\text { sewage sludge and } \\
\text { vegetal waste) }\end{array}$ & $\mathrm{Cd} / \mathrm{Pb} / \mathrm{Zn}$ \\
\hline Farmyard manure & $\mathrm{Cu} / \mathrm{Ni} / \mathrm{Zn}$ \\
\hline $\begin{array}{l}\text { Incinerated poultry } \\
\text { waste }\end{array}$ & $\mathrm{Pb}$ \\
\hline Peat & $\mathrm{Cu} / \mathrm{Pb}$ \\
\hline Poultry manure & As \\
\hline
\end{tabular}

Plant residues

Rapeseed residue
Decrease in $1 \mathrm{M}-\mathrm{NH}_{4} \mathrm{NO}_{3}$ extractable $\mathrm{Cd}$ and $\mathrm{Pb}$ Decrease in $0.01 \mathrm{M} \mathrm{CaCl}_{2}$ and TCLP extractable $\mathrm{Pb}$ Formation of hydroxypyromorphite $\left[\mathrm{Pb}_{5}\left(\mathrm{PO}_{4}\right)_{3}(\mathrm{OH})\right]$

Decrease in $1 \mathrm{M}-\mathrm{NH}_{4} \mathrm{NO}_{3}$ extractable $\mathrm{Cu}, \mathrm{Cd}$ and $\mathrm{Pb}$ Electrostatic interactions between metals and functional group

Decrease in leached metals from soil column

(1) Increase in sorption after biochar application

Decrease in bioavailability and bioaccessibility of Changes in soil $\mathrm{pH}$ after application of biochar $\mathrm{Pb}$

Decrease in $1 \mathrm{M}-\mathrm{NH}_{4} \mathrm{NO}_{3}$ extractable $\mathrm{Pb}$ Increase in $1 \mathrm{M}-\mathrm{NH}_{4} \mathrm{NO}_{3}$ extractable $\mathrm{Sb}$

(1) Decreased $\mathrm{Pb}$-i) Increased soil $\mathrm{pH}$ and ii) $\mathrm{Pb}$ sorbed on kaolinite in biochar amended soils

(2) Increased Sb-Increased Sb solubility and desorption from soil particles NA

References

Uchimiya et al., 2010

Park et al., 2011a

Cao et al., 2011

Park et al., 2011a

Beesley and Marmiroli, 2011

Ahmad et al., 2012b

Ahmad et al., 2014a

(1) Metal precipitations

(2) Increase in specific adsorption of the metals

(1) Formation of pozzolanic reaction products (CAH and CSH) under high Moon et al., 2013b soil $\mathrm{pH}$ induced by application of biochar

(2) Formation of chloropyromorphite and lead phosphate

Decrease in TCLP extractable $\mathrm{Pb}$

Decrease in EDTA extractable As, Co, Cr, Ni and ～(1) Decrease-Precipitation and increased adsorption by pH change from Khan et al., 2013 $\mathrm{Pb}$

4.02 to $4.84-5.39$

(2) Increase-High contents of metals in biochar
(1) Precipitation of metal hydroxides and carbonates through a gradual alkalinization induced by the application of composts

(2) Stimulation of As release by compost into the soil solution

(1) Decrease in $\mathrm{Cu}, \mathrm{Pb}$ and $\mathrm{Zn}$ concentration in soil

(2) Increase in As concentration in soil solution

Decrease in bioavailable fractions of $\mathrm{Cd}, \mathrm{Pb}$ and $\mathrm{Zn}$ Adsorption of metals onto soil surface

NA

Increase in $0.05 \mathrm{M}$ EDTA extractable metal

Decrease in TCLP extractable $\mathrm{Pb}$

Decrease in water extractable $\mathrm{Cu}$ and $\mathrm{Pb}$ Increase in $1 \mathrm{M}-\mathrm{NH}_{4} \mathrm{OAc}$ extractable As
Increase in adsorption on the mineral surface by increased soil $\mathrm{pH}$

Enhanced metal sorption due to increased amount of sorptive sites

(1) Increase in soil $\mathrm{pH}$

(2) Competition for sorption onto Fe-oxyhydroxides by increased DOC
Fellet et al., 2011

Jiang et al., 2012

Farrell and Jones, 2010

Castaldi et al., 2005

Paulose et al., 2007

Hashimoto et al., 2009

Kumpiene et al., 2007

Usman et al., 2013

Ok et al., 2011d

Lee et al., 2013b 
(Castaldi 등, 2005). 한편 Kumpiene 등(2007)은 토양 내 구리 와 납에 대한 안정화를 위하여 이탄(peat)을 처리하는 연구를 수행하였다. 연구결과 구리와 납이 무처리구 대비 각각 74.5 , $61.0 \%$ 감소하였으며 이는 토양의 낮은 $\mathrm{pH}$ 조건에서 유기물과 구리 및 납의 안정한 복합체 형성에 기인한 결과라고 하였다 (Kumpiene 등, 2007).

Farrell과 Jones(2010)은 오염토양에 여러 종류의 퇴비를 처리 하여 토양 내 중금속 $(\mathrm{As}, \mathrm{Cu}, \mathrm{Pb}, \mathrm{Zn})$ 안정화에 대한 연구를 수행하였다. 연구결과 구리, 납, 아연 등은 토양 용액 내 농도 가 감소하였는데 이는 퇴비가 점진적인 토양의 알칼리화 (alkalinization)를 야기하여 금속 수산화물과 탄산염 침전물을 생 성하면서 생물유효도가 감소한 것에 기인한 결과임을 보고하였 다. 그러나 퇴비 처리에 따른 토양의 알칼리화는 비소의 방출 을 증대시켜 토양 용액 내 농도를 증가시킨다고 하였다(Farrell 과 Jones, 2010). 이와 유사하게 Usman 등(2013)은 토양 내 중금속의 식물추출 시 보조제로 사용되는 합성 킬레이트제 (EDTA와 NTA)의 독성완화를 위한 첨가제로 계분을 처리하였 다. 연구결과 납과 카드뮴의 이동성 분획(mobile fraction)은 계 분 처리에 의한 영향이 없었으나, 비소의 경우 무처리구에 비 해 증가하는 것으로 나타났다. 이는 계분 처리 후 증가된 토양 의 $\mathrm{pH}$ 조건 $(6.43 \rightarrow 7.12)$ 에서 음이온 형태로 존재하는 비소의 이 동성이 증대된 것과 증가된 $\mathrm{DOC}$ 가 토양 내 비소의 $\mathrm{Fe}-$ oxyhydroxides에 대한 흡착에 대해 경합하면서 발생한 결과라 고 하였다(Usman 등, 2013).

Hashimoto 등(2009)은 사격장 토양에 소각가금류폐기물(IPW, incinerated poultry waste)을 처리하여 납의 안정화 연구를 실시 하였다. 연구결과 TCLP 용출성 납이 무처리구 대비 $90 \%$ 감소 하였는데 이는 IPW 처리 후 상승한 토양 $\mathrm{pH}$ 조건에서 광물표 면으로의 납 흡착 증대 및 IPW에 함유된 인과 납 반응에 의한 불용성의 pyromorphite 형성에 기인한다고 하였으며, EXAFS$\mathrm{LCF}$ 을 통해 IPW처리에 의한 토양 내 chloropyromorphite형성 을 확인하였다. 한편, 인과 알칼리성 염류(alkaline salts)를 함유 한 물질을 토양개량제로 과도하게 사용하는 것은 자칫 부영양 화 등과 같은 환경적 악영향의 우려로 인해 사용 시 각별한 주 의가 요구된다고 하였다(Hashimoto 등, 2009).

식물잔사(Plant residues). 식물잔사를 토양 내 중금속의 안정화 에 사용한 연구는 상대적으로 미미한 상황으로 일부 연구에서 바이오디젤(biodiesel) 생산 후 부산물로 발생하는 유채(rapeseed, Brassica napus L.) 잔사를 활용한 연구가 있다(Table 3).

$\mathrm{Ok}$ 등(2011d)은 인근 광산의 광미의 유입으로 오염된 논토양 내 카드뮴과 납을 정화하기 위하여 유채와 관행 질소시비를 혼 합하여 토양에 처리하였다. 연구결과 유채의 처리는 토양 내 이 용이 용이한 형태의 카드뮴과 납을 각각 5-14, 30-39\%까지 감 소시키며 재배되는 벼에 대한 중금속 유효도를 낮추는 것으로 나타났다. 이는 유채와 같은 유기성 잔유물의 첨가를 통해 토 양 내 중금속이 다른 고상 분획(solid-phase fractions)과 반응하 면서 안정화되는 것이며, 이는 점토광물, 탄산염, 수산화물로의 흡착이나 중금속 탄산염, 수산화물이나 인산염으로의 침전에 기 인한 결과라고 하였다(Ok 등, 2011d).

유기성 물질 요약. 유기성 물질인 바이오차와 바이오 고형물의 토양 처리에 의한 중금속 안정화를 Table 3에 요약하여 나타내 었다. 바이오차의 토양 처리는 1) 바이오차 표면으로의 흡착, 2) $\mathrm{pH}$ 상승에 기인한 토양 흡착 증대, 3) 침전물 형성 등에 의해 중금속을 안정화하는 것으로 보고되었다. 그러나 바이오차는 생
산 시에 에너지 소비적인 열분해 과정이 요구되므로 이에 대한 경제적인 측면의 평가가 필요하다. 바이오 고형물의 토양 처리 는 1) 토양 표면의 중금속 흡착 증대, 2) 유기물과의 안정한 복 합체 형성에 의해 중금속을 안정화하였다. 그러나 $\mathrm{pH}$ 상승에 의해 토양으로부터의 비소 방출이 증가할 수 있어 사용 시 이 에 대한 주의가 필요하다.

\section{기타물질(Others)}

전술한 부산물 폐자원 외에 토양 내 중금속의 안정화에 사용되 는 개량제로는 침철석(goethite), 영가철(ZVI, zerovalent iron), 철 산화물 등의 철 함유물질과 제올라이트(zeolite) 등이 있으며, 이에 대한 대표적인 연구결과들은 다음과 같다.

토양의 $\mathrm{pH}$ 와 철 산화물의 함량은 토양 내 비소의 생물유효 도를 제어하는 가장 중요한 토양 특성이다(Lombi 등, 2004). Hartley 등(2004)은 토양 내 비소의 안정화를 위하여 철 산화물인 침철석 $(\alpha-\mathrm{FeOOH})$, iron grit, iron(II) sulphate, iron(III) sulphate를 토양에 처리하였다. 연구결과 용출되는 비소의 농도가 감소하였 는데 이는 $\mathrm{pH}$ 감소에 의해 증대된 철 산화물로의 비소 흡착에 의한 결과라고 하였다(Hartley 등, 2004). 이와 달리 납과 카드 뮴의 용출은 증가하였는데 이를 통해 다양한 중금속으로 오염 된 지역에 대한 개량제의 처리 이전에 토양 조사가 필요하다고 하였다(Hartley 등, 2004). 이와 함께 Kumpiene 등(2006)은 비 소, 크롬, 구리 함유 목재방부재로 오염된 토양에 영가철을 1 $\mathrm{wt} \%$ 수준으로 처리하였다. 연구결과 영가철 처리를 통해 비소, 크롬, 구리의 교환성 분획, 용출농도, 토양 공극수(pore water) 내 농도가 감소하였다. 이는 영가철이 습토 내에서 부식 (corrosion)되면서 $\mathrm{Fe}$ 반응성 표면으로 비소가 흡착된 것과 함 께 비소와 $\mathrm{Fe}^{3+}$ 의 ferric arsenates $\left(\mathrm{FeAsO}_{4} \cdot 2 \mathrm{H}_{2} \mathrm{O}\right.$ ) 공침전(coprecipitation)된 것에 기인한 감소라고 하였다. 크롬의 경우 총 농도는 높았으나 처리 전 - 후 크롬이 이동성이 낮은 $\mathrm{Cr}(\mathrm{III})$ 으 로 존재하였고, 이는 중성-약산성의 $\mathrm{pH}$ 조건이 $\mathrm{Cr}(\mathrm{III})$ 로의 환원 조건을 제공한 것에 기인한 결과라고 하였다. 일부 $\mathrm{Cr}(\mathrm{VI})$ 의 경 우도 자연적인 $\mathrm{Cr}(\mathrm{III})$ 으로의 환원을 통해 감소하였다. 구리의 경우 농도는 감소하였으나 상대적으로 낮은 감소효율을 보였는 데 이는 토양용액 내 이온강도(ionic strength) 및 토양의 산성 화에 기인한 결과라고 하였다(Kumpiene 등, 2006). Lim 등 (2010)은 비소오염토양의 정화를 위해 영가철을 $1,3,5 \mathrm{wt} \%$ 수준으로 처리하였다. 연구결과 영가철의 처리는 $1 \mathrm{M}-\mathrm{HCl}$ 및 $0.01 \mathrm{M} \mathrm{CaCl}$ 용출성 비소를 각각 $40,90 \%$ 이상 감소시켰는데 이는 영가철 처리에 의한 불용성의 철-비소 화합물 생성에 기 인한 결과라고 하였다(Lim 등, 2010). 이와 함께 Ok 등(2011a) 은 논토양 내 카드뮴의 안정화를 위해 영가철을 $5 \mathrm{wt} \%$ 수준으 로 처리하였으며 연구결과 영가철 처리를 통해 토양 내 존재하 는 카드뮴 중 생물에게 유효한 형태인 교환성 분획과 흡착 분 획(adsorbed fraction)이 무처리구 대비 각각 $98,54 \%$ 감소하였 다. 이는 영가철의 처리 후 카드뮴 흡착이 증대된 것에 기인한 결과라고 하였다(Ok 등, 2011a).

Querol 등(2006)은 FA로부터 합성하여 제조한 제올라이트를 오염토양 내 중금속 $(\mathrm{Cd}, \mathrm{Co}, \mathrm{Cu}, \mathrm{Ni}, \mathrm{Zn})$ 의 용출저감을 위해 토양에 처리하였다. 연구결과 중금속의 용출이 최대 95-99\%까 지 감소하는 것으로 나타났으며, 이는 제올라이트 처리 후 $\mathrm{pH}$ 상승에 의한 토양 내 일라이트(illite)로의 중금속 흡착증대와 중 
Table 4 Applications of various materials for stabilization of metal(loid)s in the soils

\begin{tabular}{|c|c|c|c|c|}
\hline Amendments & Target metals & Effects of amendments & Main mechanisms of metal stabilization & References \\
\hline Iron (III) sulphates & $\mathrm{As} / \mathrm{Cd} / \mathrm{Cu} / \mathrm{Pb} / \mathrm{Zn}$ & $\begin{array}{l}\text { Decrease in leachability of } \mathrm{As} \\
\text { Increase in leachability of } \mathrm{Pb} \text { and } \mathrm{Cd}\end{array}$ & $\begin{array}{l}\text { (1) Increase in adsorption of As onto Fe-oxides surface in decreased } \mathrm{pH} \\
\text { (2) Decreased } \mathrm{pH}\end{array}$ & Hartley et al., 2004 \\
\hline $\begin{array}{l}\text { Goethite } \\
(\alpha-\mathrm{FeOOH})\end{array}$ & $\mathrm{As} / \mathrm{Cd} / \mathrm{Cu} / \mathrm{Pb} / \mathrm{Zn}$ & $\begin{array}{l}\text { Decrease in leachability of } \mathrm{As} \\
\text { Increase in leachability of } \mathrm{Pb} \text { and } \mathrm{Cd}\end{array}$ & $\begin{array}{l}\text { (1) Increase in adsorption of As onto Fe-oxides surface in decreased } \mathrm{pH} \\
\text { (2) Decreased } \mathrm{pH}\end{array}$ & Hartley et al., 2004 \\
\hline Natural red earth & $\mathrm{Pb}$ & Decrease in $1 \mathrm{M}-\mathrm{NH}_{4} \mathrm{OAc}$ extractable $\mathrm{Pb}$ & Adsorption and formation of inner sphere complexes with $\mathrm{Pb}$ & Almaroai et al., 2014b \\
\hline $\begin{array}{l}\text { Zeolite } \\
\text { (synthesized) }\end{array}$ & $\mathrm{Cd} / \mathrm{Co} / \mathrm{Cu} / \mathrm{Ni} / \mathrm{Zn}$ & $\begin{array}{l}\text { Decrease in water extractable } \mathrm{Cd}, \mathrm{Co}, \mathrm{Cu}, \mathrm{Ni} \text { and } \\
\mathrm{Zn}\end{array}$ & $\begin{array}{l}\text { (1) Metal adsorption onto illite surfaces } \\
\text { (2) Precipitation of metal hydroxides }\end{array}$ & Querol et al., 2006 \\
\hline (natural) & $\mathrm{Cd} / \mathrm{Pb} / \mathrm{Zn}$ & $\begin{array}{l}\text { Decrease in bioavailable fractions of } \mathrm{Cd}, \mathrm{Pb} \text { and } \\
\mathrm{Zn}\end{array}$ & Adsorption of metals onto soil surface & Castaldi et al., 2005 \\
\hline (natural) & $\mathrm{Cd} / \mathrm{Pb} / \mathrm{Zn}$ & $\begin{array}{l}\text { Decrease in bioavailable fractions and increase in } \\
\text { residual fraction }\end{array}$ & $\begin{array}{l}\text { A blocking mechanism due to ion exchange and metal adsorption into the } \\
\text { lattice of tectosilicate in zeolite }\end{array}$ & Garau et al., 2007 \\
\hline \multirow[t]{3}{*}{$\begin{array}{l}\text { Zerovalent iron } \\
(\mathrm{ZVI})\end{array}$} & $\mathrm{As} / \mathrm{Cr} / \mathrm{Cu} / \mathrm{Zn}$ & $\begin{array}{l}\text { Decrease in exchangeable fraction of } \mathrm{As}, \mathrm{Cr}, \mathrm{Cu} \\
\text { and } \mathrm{Zn}\end{array}$ & $\begin{array}{l}\text { (1) Adsorption of As on the Fe reactive surfaces during corrosion in moist } \\
\text { soil } \\
\text { (2) Co-precipitation as ferric arsenates }\left(\mathrm{FeAsO}_{4} \cdot 2 \mathrm{H}_{2} \mathrm{O}\right)\end{array}$ & Kumpiene et al., 2006 \\
\hline & As & $\begin{array}{l}\text { Decrease in } 1 \mathrm{M}-\mathrm{HCl} \text { and } 0.01 \mathrm{M}-\mathrm{CaCl}_{2} \\
\text { extractable As }\end{array}$ & $\begin{array}{l}\text { Formation of insoluble Fe-As compound (amorphous scorodite, } \\
\mathrm{FeAsO}_{4} \cdot \mathrm{xH}_{2} \mathrm{O} \text { ) }\end{array}$ & Lim et al., 2010 \\
\hline & $\mathrm{Cd}$ & Decrease in exchangeable and adsorbed $\mathrm{Cd}$ & Adsorption & Ok et al., 2011a \\
\hline
\end{tabular}




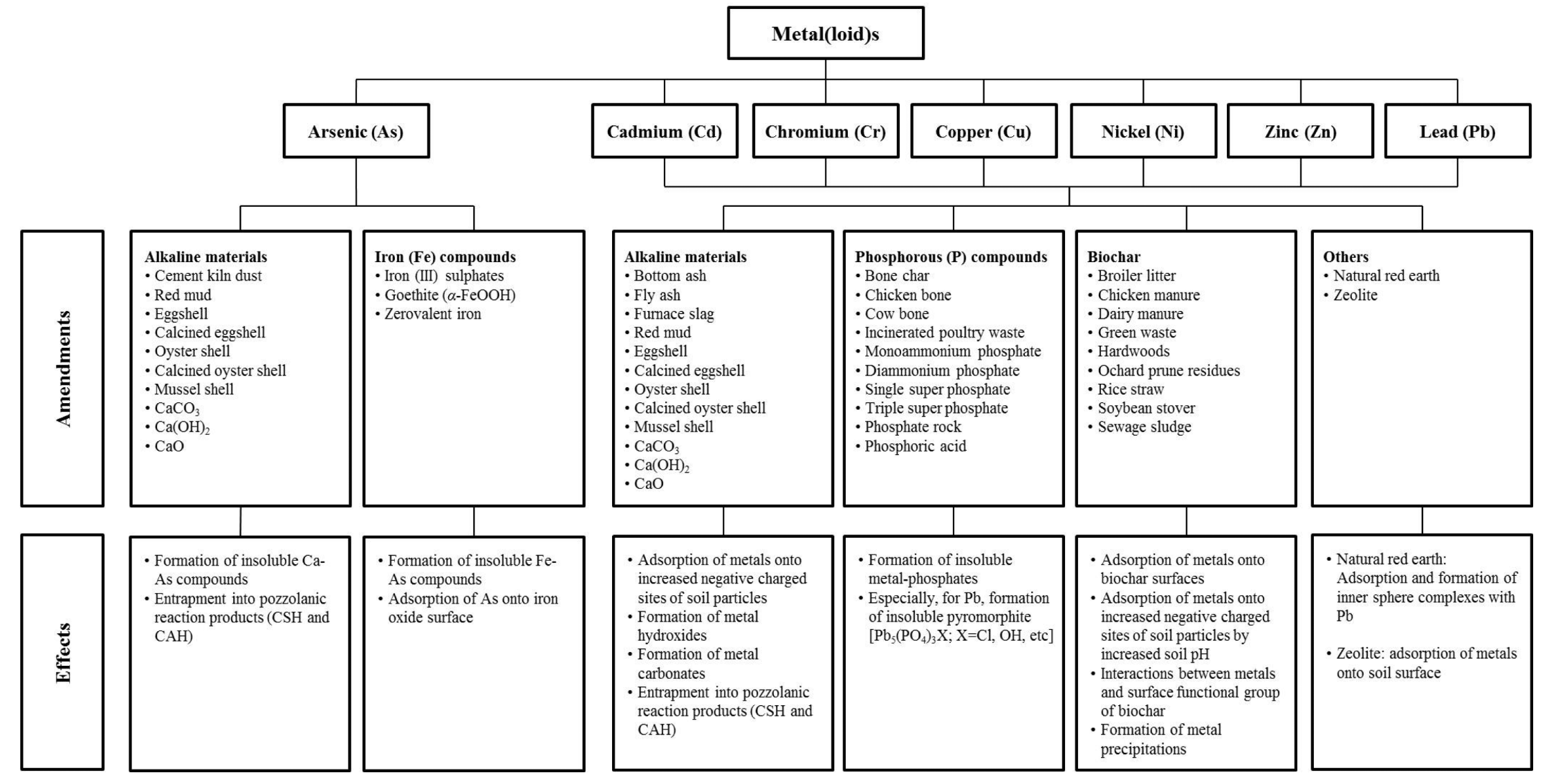

Fig. 1 Schematic description of metal(loid)s stabilization in the soils. 
금속 수산화물로의 침전 등에 기인한 결과라고 하였다. 또한 Querol 등(2006)은 제올라이트가 다른 알칼리물질의 처리보다 중금속 이동성 증대에 대한 위험성이 낮으며, 높은 수준의 $\mathrm{CEC}$ 로 인해 용해성 중금속 농도를 감소시킬 수 있다고 하였다. 이 와 함께 Garau 등(2007)은 광산활동으로 오염된 토양의 납, 카 드뮴, 아연의 안정화를 위하여 제올라이트를 처리하는 연구를 수행하였다. 6개월 후 연속추출을 통한 중금속의 분획화 결과 제올라이트 처리를 통해 토양 내 납, 카드뮴, 아연은 생물유효 성 분획이 감소하고 잔류성 분획이 증가하였다. 이는 제올라이 트의 tectosilicate lattice(텍토 규산염 격자)에 대한 중금속 흡착 의 증가, 이온교환 등에 의한 결과라고 하였다(Garau 등, 2007). 기타물질 요약. 철 함유물질과 제올라이트의 토양 처리에 의한 중금속 안정화를 Table 4에 요약하여 나타내었다. 철 함유물질 은 주로 비소의 안정화에 사용되며, 1) 철 산화물로의 흡착 및 2) 철-비소 공침전 등에 의해 비소를 안정화하는 것으로 보고되 었다. 그러나 일부 철 산화물의 경우 $\mathrm{pH}$ 를 하강시켜 타 중금속 의 용출을 증가시키므로 사용 시 이에 대한 주의가 필요하다. 한편, 제올라이트의 처리는 토양 $\mathrm{pH}$ 를 상승시키며 1) 중금속 흡착 증대, 2) 수산화물 침전 등에 의해 토양 내 중금속을 안 정화하는 것으로 보고되었다.

\section{결론 및 향후 연구방향}

본 연구에서는 최근 몇 년간 보고된 토양 중금속 정화용 개량 제, 특히 부산물 폐자원에 의한 중금속 안정화 연구에 대해 살 펴보았다. 연구결과 알칼리물질 및 인 함유물질과 함께 이와 유 사한 특성을 지닌 부산물 폐자원에 대한 연구가 가장 많이 이 루어지고 있었다. 또한 다양한 바이오매스로부터 생산한 바이오 차의 토양 적용에 관한 연구가 이루어지고 있었다. 알칼리물질 의 경우 패각류 및 난각류, 알칼리성 산업부산물, 석회물질이 활용되고 있었다. 중금속 유형별 개량제 선택과 처리에 따른 토 양 내 중금속 안정화 기작을 Fig. 1에 나타내었다. 알칼리물질 의 토양 처리는 토양의 $\mathrm{pH}$ 를 높이며 이를 통해 1) 토양의 음 전하 부위가 증대되어 양이온성 중금속의 흡착 증가, 2) 알칼리 조건에서 중금속 수산화물 형성, 3) 중금속 탄산염 형성, 4) 포 졸란 반응 산물 $(\mathrm{CSH}, \mathrm{CAH})$ 형성에 의한 entrapment, 5) ettringite 형성 후 중금속 이온의 치환 등에 의해 중금속을 안 정화하는 것으로 보고되었다. 그러나 일부의 경우 $\mathrm{pH}$ 상승을 통해 증가된 토양 내 $\mathrm{DOC}$ 와 중금속이 결합하면서 중금속의 이 동성이 증가할 수 있어 이에 대한 주의가 필요하다. 인 함유물 질의 경우 동물기원물질(동물뼈, 축분)과 일반물질(phosphate rock, phosphoric acid 등)이 활용되고 있으며 인 함유물질의 토 양 처리는 주로 1) 중금속-인산염 침전물 형성, 2) pyromorphite 형태의 침전물 형성 등에 의해 토양 내 중금속을 안정화하는 것으로 보고되었다. 그러나 인의 경우 음이온성으로 존재하는 비소, 셀레늄, 안티몬과 토양 내 흡착부위에 대해 경합하므로 토양으로부터 용출되는 비소, 셀레늄과 안티몬이 증가할 수 있 어 이에 대한 주의가 필요하다. 이와 함께 인 함유물질의 과도 한 사용은 수계에 대한 부영양화 원인으로 작용할 수 있어 처 리 시 각별한 주의가 필요하다. 유기성 물질의 경우 바이오차 의 토양 처리는 주로 1) 바이오차 표면 흡착, 2) 처리 후 $\mathrm{pH}$ 상승에 따른 토양으로의 흡착 증대, 3) 침전물 형성 등에 의해 중금속을 안정화하는 것으로 보고되었다. 그러나 바이오차의 경
우 생산재료의 확보 후 추가적으로 에너지를 소모하는 열분해 과정이 요구되므로 이에 대한 경제적인 측면의 평가가 필요하 다. 바이오 고형물의 토양 처리는 1) 토양 표면으로의 중금속 흡착 증대, 2) 유기물과 중금속의 안정한 복합체 형성에 의해 중금속을 안정화하는 것으로 보고되었다. 그러나 $\mathrm{pH}$ 상승에 의 해 토양으로부터의 비소 방출이 증가하는 것으로 보고되었다. 이와 함께 철 함유물질은 주로 비소의 안정화를 위해 처리되었 으며, 1) 철 산화물로의 흡착, 2) 철-비소 공침전 등을 통해 비 소를 안정화하는 것으로 보고되었다. 그러나 일부 철 산화물 개 량제의 경우 토양의 $\mathrm{pH}$ 를 하강시켜 다른 중금속의 용출을 증 가시키는 것으로 나타났다. 한편, 제올라이트의 처리는 토양의 $\mathrm{pH}$ 를 상승시켜, 1) 중금속 흡착 증대, 2) 수산화물 침전 등에 의해 토양 내 중금속을 안정화하는 것으로 보고되었다. 이와 같 이 현재 연구되고 있는 중금속 안정화를 위한 개량제들은 고유 의 장 - 단점이 있어 토양 처리 전 안정화 대상 중금속 원소와 의 반응을 고려해야 할 것으로 판단된다.

향후 연구방향으로는 개량제의 처리 후 XAS (X-ray absorption spectroscopy), XRD, SEM-EDX elemental dot mapping 등의 방법을 활용하여 토양 내 중금속 화학종에 대한 정확한 분석을 실시함으로써 안정화에 대한 장기적 안정성을 평가하는 연구가 보다 활발하게 이루어져야 할 것으로 판단된다. 이와 함께 현 재 부산물 폐자원 개량제의 활용은 실험실 규모(lab scale)의 연 구가 대부분이므로 이에 대한 현장 규모(field scale)의 연구를 통해 현장 적용성을 높이는 노력이 필요하다. 또한 오염토양의 특성상 상이한 화학적 특성을 나타내는 여러 가지 중금속이 공 존하는 경우가 많아 이를 동시에 안정화할 수 있는 개량제의 개발이 필요하다. 세부적으로는 각종 개량제들의 혼합 처리 연 구, 최적처리량 산정 등에 관한 연구가 필요할 것으로 판단된다.

\section{초 록}

토양 중금속 안정화를 위해 농축수산 부산물, 산업부산물 등과 같은 다양한 폐자원이 활용되고 있다. 일례로 석회, 패각류, 난 각류, 산업부산물 등의 알칼리물질, 동물의 뼈 및 인산용액, 인 광석 등의 인 함유물질, 퇴비(compost), 가축분(manure), 바이오 차(biochar) 등의 유기성물질과 이 외에도 영가철, 제오라이트 (zeolite) 등의 다양한 물질들을 토양 내 중금속 안정화의 소재 로 활용하기 위한 효율성, 적용성 연구가 진행되고 있다. 이들 물질에 대한 토양 적용 후 중금속 안정화 기작은 일부 보고된 바 있으나 장기적 안정성과 현장 적용성을 평가한 연구는 여전 히 부족한 실정이다. 본 연구에서는 여러 가지 폐자원을 활용 한 선행 연구들에서 제시된 토양 중금속 안정화 관련 내용을 요약하였다.

Keywords adsorbent - bioavailability - biochar - soil pollution · soil remediation $\cdot$ stabilizer $\cdot$ waste management

감사의 글 본 연구는 2012년도 정부(교육과학기술부)의 재원으로 한국연구 재단의 기초연구사업(과제번호 2012R1A1B3001409)지원 및 농촌진흥청 국 립농업과학원의 공동연구사업(Project No. PJ009828012014)의 지원으로 수 행되었습니다.

\section{Abbreviations}

ALC, autoclave light-weight concrete 
BA, bottom ash

$\mathrm{CAH}$, calcium aluminate hydrate

CEC, cation exchange capacity

CKD, cement kiln dust

CMDS, coal mine drainage sludge

$\mathrm{CSH}$, calcium silicate hydrate

DAP, diammonium phosphate

DOC, dissolved organic carbon

EDDS, ethylene diamine-N, N'-disuccinic acid

EDTA, ethylene diaminetetra acetic acid

EXAFS-LCF, extended X-ray absorption fine structure-linear combination fitting

FA, fly ash

FS, furnace slag

IPW, incinerated poultry waste

MSW, municipal solid waste

PBET, physiologically based extraction test

$\mathrm{PR}$, phosphate rock

$\mathrm{RM}$, red mud

SEM-EDX, scanning electron microscope-energy dispersive

$\mathrm{X}$-ray spectrometer

TCLP, toxicity characteristic leaching procedure

TSP, triple super phosphate

XAS, X-ray absorption spectroscopy

XRD, X-ray diffraction

XRPD, X-ray powder diffraction

ZVI, zerovalent iron

\section{References}

Abd El-Azeem SAM, Ahmad M, Usman ARA, Kim KR, Oh SE, Lee SS et al. (2013) Changes of biochemical properties and heavy metal bioavailability in soil treated with natural liming materials. Environ Earth Sci 70, 3411-20.

Ahmad M, Hashimoto Y, Moon DH, Lee SS, and Ok YS (2012a) Immobilization of lead in a Korean military shooting range soil using eggshell waste: an integrated mechanistic approach. J Hazard Mater 209-210, 392-401.

Ahmad M, Lee SS, Lim JE, Lee SE, Cho JS, Moon DH et al. (2014a) Speciation and phytoavailability of lead and antimony in a small arms range soil amended with mussel shell, cow bone and biochar: EXAFS spectroscopy and chemical extractions. Chemosphere 95, 433-41.

Ahmad M, Lee SS, Yang JE, Ro HM, Lee YH, and Ok YS (2012b) Effects of soil dilution and amendments (mussel shell, cow bone, and biochar) on $\mathrm{Pb}$ availability and phytotoxicity in military shooting range soil. Ecotoxicol Environ Saf 79, 225-31.

Ahmad M, Moon DH, Lim KJ, Shope CL, Lee SS, Usman ARA et al. (2012c) An assessment of the utilization of waste resources for the immobilization of $\mathrm{Pb}$ and $\mathrm{Cu}$ in the soil from a Korean military shooting range. Environ Earth Sci 67, 1023-31.

Ahmad M, Moon DH, Wazne M, Kim HJ, Lee YH, and Ok YS (2013) Effects of natural and calcined oyster shells on antimony solubility in shooting range soil. J Korean Soc Appl Biol Chem 56, 461-4.

Ahmad M, Rajapaksha AU, Lim JE, Zhang M, Bolan N, Mohan D et al. (2014b) Biochar as a sorbent for contaminant management in soil and water: A review. Chemosphere 99, 19-33.

Almaroai YA, Vithanage M, Rajapaksha AU, Lee SS, Dou X, Lee YH et al. (2014) Natural and synthesized iron-rich amendments for As and $\mathrm{Pb}$ immobilization in agricultural soil. Chem Ecol 30, 267-79.
Baker LR, Pierzynski GM, Hettiarachchi GM, Scheckel KG, and Newville M (2012) Zinc speciation in proximity to phosphate application points in a lead/zinc smelter-contaminated soil. J Environ Qual 41, 1865-73.

Basta NT and McGowen SL (2004) Evaluation of chemical immobilization treatments for reducing heavy metal transport in a smelter-contaminated soil. Environ Pollut 127, 73-82.

Beesley L and Marmiroli M (2011) The immobilization and retention of soluble arsenic, cadmium and zinc by biochar. Environ Pollut 159, 474 80.

Bolan N, Kunhikrishnan A, Thangarajan R, Kumpiene J, Park J, Makino T et al. (2014) Remediation of heavy metal(loid)s contaminated soils - To mobilize or to immobilize? J Hazard Mater 266, 141-66.

Brallier S, Harrison RB, Henry CL, and Dongsen X (1996) Liming effects on availability of $\mathrm{Cd}, \mathrm{Cu}, \mathrm{Ni}$ and $\mathrm{Zn}$ in a soil amended with sewage sludge 16 years previously. Water Air Soil Pollut 86, 195-206.

Cao X, Ma L, Liang Y, Gao B, and Harris W (2011) Simultaneous immobilization of lead and atrazine in contaminated soils using dairymanure biochar. Environ Sci Technol 45, 4884-9.

Cao X, Wahbi A, Ma L, Li B, and Yang Y (2009) Immobilization of Zn, Cu, and $\mathrm{Pb}$ in contaminated soils using phosphate rock and phosphoric acid. $J$ Hazard Mater 164, 555-64.

Castaldi P, Santona L, and Melis P (2005) Heavy metal immobilization by chemical amendments in a polluted soil and influence on white lupin growth. Chemosphere 60, 365-71.

Chen SB, Zhu YG, Ma YB, and McKay G (2006) Effect of bone char application of $\mathrm{Pb}$ bioavailability in a $\mathrm{Pb}$-contaminated soil. Environ Pollut 139, 433-9.

Chrysochoou M, Dermatas D, and Grubb DG (2007) Phosphate application to firing range soils for $\mathrm{Pb}$ immobilization: The unclear role of phosphate. $J$ Hazard Mater 144, 1-14.

Conesa HM, Wieser M, Gasser M, Hockmann K, Evangelou MWH, Studer B et al. (2010) Effects of three amendments on extractability and fractionation of $\mathrm{Pb}, \mathrm{Cu}, \mathrm{Ni}$ and $\mathrm{Sb}$ in two shooting range soils. $J$ Hazard Mater 181, 845-50.

Dermatas D and Moon DH (2006) Chromium leaching and immobilization in treated soils. Environ Eng Sci 23, 77-87.

Farrell M and Jones DL (2010) Use of composts in the remediation of heavy metal contaminated soil. J Hazard Mater 175, 575-82.

Fayiga AO and Ma LQ (2006) Using phosphate rock to immobilize metals in soil and increase arsenic uptake by hyperaccumulator Pteris vittata. Sci Total Environ 359, 17-25.

Fellet C, Marchiol L, Delle Vedove G, and Peressotti A (2011) Application of biochar on mine tailings: Effects and perspectives for land reclamation. Chemosphere 83, 1262-7.

Garau G, Castaldo P, Santona L, Deiana P, and Melis P (2007) Influence of red mud, zeolite and lime on heavy metal immobilization, culturable heterotrophic microbial populations and enzyme activities in a contaminated soil. Geoderma 142, 47-57.

Gray CW, Dunham SJ, Dennis PG, Zhao FJ, and McGrath SP (2006) Field evaluation of in situ remediation of a heavy metal contaminated soil using lime and red-mud. Environ Pollut 142, 530-9.

Gougar MLD, Scheetz BE, and Roy DM (1996) Ettringite and C-S-H Portland cement phases for waste ion immobilization: A review. Waste Manage 16, 295-303.

Hartley W, Edwards R, and Lepp NW (2004) Arsenic and heavy metal mobility in iron oxide-amended contaminated soils as evaluated by shortand long-term leaching tests. Environ Pollut 131, 495-504.

Hashimoto Y, Matsufuru H, Takaoka M, Tanida H, and Sato T (2009) Impacts of chemical amendment and plant growth on lead speciation and enzyme activities in a shooting range soil: an X-ray absorption fine structure investigation. J Environ Qual 38, 1420-8.

Hong CO, Gutierrez J, Yun SW, Lee YB, Yu C, and Kim PJ (2009) Heavy metal contamination of arable soil and corn plant in the vicinity of a zinc smelting factory and stabilization by liming. Arch Environ Contam Toxicol 56, 190-200.

Jiang J, Xu RK, Jiang TY, and Li Z (2012) Immobilization of Cu(II), Pb(II) and $\mathrm{Cd}(\mathrm{II})$ by the addition of rice straw derived biochar to a simulated polluted Ultisol. J Hazard Mater 229-230, 145-50. 
Khan S, Chao C, Waqas M, Arp HPH, and Zhu YG (2013) Sewage sludge biochar influence upon rice (Oryza sativa $\mathrm{L}$ ) yield, metal bioaccumulation and greenhouse gas emissions from acidic paddy soil. Environ Sci Technol 47, 8624-32.

Kim MN, Kim WG, Lee SM, and Yang JK (2009) Removal of Cu(II) with the recycled hydroxylapatite from animal bones. J Korean Soc Environ Eng 31, 735-42.

Kostarelos K, Reale D, Dermatas D, Rao E, and Moon DH (2006) Optimum dose of lime and fly ash for treatment of hexavalent chromiumcontaminated soil. Water Air Soil Poll: Focus, 6, 171-89.

Kumpiene J, Lagerkvist A, and Maurice C (2007) Stabilization of Pb- and $\mathrm{Cu}-\mathrm{contaminated} \mathrm{soil} \mathrm{using} \mathrm{coal} \mathrm{fly} \mathrm{ash} \mathrm{and} \mathrm{peat.} \mathrm{Environ} \mathrm{Pollut} \mathrm{145,}$ 365-73.

Kumpiene J, Lagerkvist A, and Maurice C (2008) Stabilization of As, Cr, Cu, $\mathrm{Pb}$ and $\mathrm{Zn}$ in soil using amendments - A review. Waste Manage 28, 215 25 .

Kumpiene J, Ore S, Renella G, Mench M, Lagerkvist A, and Maurice C (2006) Assessment of zerovalent iron for stabilization of chromium, copper, and arsenic in soil. Environ Pollut 144, 62-9.

Lee KY, Moon DH, Lee SH, Kim KW, Cheong KH, Park JH et al. (2013a) Simultaneous stabilization of arsenic, lead, and copper in contaminated soil using mixed waste resources. Environ Earth Sci 69, 1813-20.

Lee SH, Ji W, Lee WS, Koo N, Koh IH, Kim MS et al. (2014) Influence of amendments and aided phytostabilization on metal availability and mobility in $\mathrm{Pb} / \mathrm{Zn}$ mine tailings. J Environ Manage 139, 15-21.

Lee SH, Lee JS, Choi YJ, and Kim JG (2009) In situ stabilization of cadmium-, lead-, and zinc-contaminated soil using various amendments. Chemosphere 77, 1069-75.

Lee SS, Lim JE, Abd El-Azeem SAM, Choi B, Oh SE, Moon DH et al (2013b) Heavy metal immobilization in soil near abandoned mines using eggshell waste and rapeseed residue. Environ Sci Pollut Res 20, 171926.

Lee TM, Lai HY, and Chen ZS (2004) Effect of chemical amendments on the concentration of cadmium and lead in long-term contaminated soils. Chemosphere 57, 1459-71.

Lim JE, Ahmad M, Lee SS, Shope CL, Hashimoto Y, Kim KR et al. (2013a) Effects of lime-based waste materials on immobilization and phytoavailability of cadmium and lead in contaminated soil. Clean-Soil Air Water 41, 1235-41.

Lim JE, Ahmad M, Usman ARA, Lee SS, Jeon WT, Oh SE et al. (2013b) Effect of natural and calcined poultry waste on $\mathrm{Cd}, \mathrm{Pb}$ and As mobility in contaminated soil. Environ Earth Sci 69, 11-20.

Lim JE, Kim HW, Jeong SH, Lee SS, Yang JE, Kim KH et al. (2014) Characterization of burcucumber biochar and its potential as an adsorbent for veterinary antibiotics in water. J Appl Biol Chem 57, 6572.

Lim JE, Kim KR, Lee SS, Kwon OK, Yang JE, and Ok YS (2010) Stabilization of As (arsenic $(\mathrm{V})$ or roxarsone) contaminated soils using zerovalent iron and basic oxygen furnace slag. J Korean Soc Environ Eng 32, 631-8.

Lim JE, Moon DH, Kim D, Kwon OK, Yang JE, and Ok YS (2009) Evaluation of the feasibility of oyster-shell and eggshell wastes for stabilization of arsenic-contaminated soil. J Korean Soc Environ Eng 31, 1095-1104.

Lombi E, Hamon RE, Wieshammer G, McLaughlin MJ, and McGrath SP (2004) Assessment of the use of industrial by-products to remediate a copper- and arsenic-contaminated soil. J Environ Qual 33, 901-10.

Moon DH, Cheong KH, Khim J, Wazne M, Hyun S, Park JH et al. (2013a) Stabilization of $\mathrm{Pb}^{2+}$ and $\mathrm{Cu}^{2+}$ contaminated firing range soil using calcined oyster shells and waste cow bones. Chemosphere 91, 1349-54.

Moon DH, Cheong KH, Kim TS, Khim J, Choi SB, Moon OR et al. (2009) Stabilization of As in soil contaminated with chromated copper arsenate (CCA) using calcinated oyster shells. Korean J Environ Agric 28, 37885.
Moon DH, Cheong KH, Kim TS, Khim J, Choi SB, Ok YS et al. (2010) Stabilization of $\mathrm{Pb}$ contaminated army firing range soil using calcined waste oyster shells. J Korean Soc Environ Eng 32, 185-92.

Moon DH, Kim KY, Yoon IH, Grubb DG, Shin DY, Cheong KH et al. (2011) Stabilization of arsenic-contaminated mine tailings using natural and calcined oyster shells. Environ Earth Sci 64, 597-605.

Moon DH, Park JW, Chang YY, Ok YS, Lee SS, Ahmad M et al. (2013b) Immobilization of lead in contaminated firing range soil using biochar. Environ Sci Pollut Res 20, 8464-71.

Moon DH, Park JW, Cheong KH, Hyun S, Koutsospyros A, Park JH et al. (2013c) Stabilization of lead and copper contaminated firing range soil using calcined oyster shells and fly ash. Environ Geochem Health 35, 705-14.

Moon DH, Wazne M, Yoon IH, and Grubb DG (2008) Assessment of cement kiln dust (CKD) for stabilization/solidification (S/S) of arsenic contaminated soils. J Hazard Mater 159, 512-8.

Ok YS, Kim SC, Kim DG, Skousen JG, Lee JS, Cheong YW et al. (2011a) Ameliorants to immobilize $\mathrm{Cd}$ in rice paddy soils contaminated by abandoned metal mines in Korea. Environ Geochem Health 33, 23-30.

Ok YS, Lee SS, Jeon WT, Oh SE, Usman ARA, and Moon DH (2011b) Application of eggshell waste for the immobilization of cadmium and lead in a contaminated soil. Environ Geochem Health, 33, 31-9.

Ok YS, Lim JE, and Moon DH (2011c) Stabilization of $\mathrm{Pb}$ and $\mathrm{Cd}$ contaminated soils and soil quality improvements using waste oyster shells. Environ Geochem Health 33, 83-91.

Ok YS, Oh SE, Ahmad M, Hyun S, Kim KR, Moon DH et al. (2010) Effects of natural and calcined oyster shells on $\mathrm{Cd}$ and $\mathrm{Pb}$ immobilization in contaminated soils. Environ Earth Sci 61, 1301-8.

Ok YS, Usman ARA, Lee SS, Abd El-Azzem SAM, Choi B, Hashimoto Y et al. (2011d) Effects of rapeseed residue on lead and cadmium availability and uptake by rice plants in heavy metal contaminated paddy soil. Chemosphere 85, 677-82.

Park JH, Choppala GK, Bolan NS, Chung JW, and Chuasavathi T (2011a) Biochar reduces the bioavailability and phytotoxicity of heavy metals. Plant Soil, 348, 439-51.

Park JH, Lamb D, Paneerselvam P, Choppala G, Bolan N, and Chung JW (2011b) Role of organic amendments on enhanced bioremediation of heavy metal(loid) contaminated soils. J Hazard Mater 185, 549-74.

Paulose B, Datta SP, Rattan RK, and Chhonkar PK (2007) Effect of amendments on the extractability, retention and plant uptake of metals on a sewage-irrigated soil. Environ Pollut 146, 19-24.

Querol X, Alastuey A, Morento N, Alvarez-Ayuso E, García-Sánchez A, Cama J et al. (2006) Immobilization of heavy metals in polluted soils by the addition of zeolitic material synthesized from coal fly ash. Chemosphere 62, 171-80.

Scheckel KG and Ryan JA (2004) Spectroscopic speciation and quantification of lead in phosphate-amended soils. J Environ Qual 33, 1288-95.

Tomasevic DD, Dalmacija MB, Prica MDj, Dalmacija BD, Kerkez DV, Beèeliæ-Tomin MR et al. (2013) Use of fly ash for remediation of metals polluted sediment - Green remediation. Chemosphere 92, 1490-7.

Uchimiya M, Lima IM, Klasson KT, Chang SC, Wartelle LH, and Rodgers JE (2010) Immobilization of heavy metals ions $\left(\mathrm{Cu}^{\mathrm{II}}, \mathrm{Cd}^{\mathrm{II}}, \mathrm{Ni}^{\mathrm{II}}\right.$, and $\left.\mathrm{Pb}{ }^{\mathrm{II}}\right)$ by broiler litter-derived biochars in water and soil. J Agric Food Chem 58, 5538-44.

USEPA (2008) Green Remediation: Incorporating Sustainable Environmental Practices into Remediation of Contaminated Sites. EPA 542-R-08-002, United States Environmental Protection Agency, USA.

Usman ARA, Almaroai YA, Ahmad M, Vithanage M, and Ok YS (2013) Toxicity of synthetic chelators and metal availability in poultry manure amended $\mathrm{Cd}, \mathrm{Pb}$, and As contaminated agricultural soil. J Hazard Mater 262, 1022-30.

Zhao XL and Masaihiko S (2007) Amelioration of cadmium polluted paddy soils by porous hydrated calcium silicate. Water Air Soil Pollut 183, 309-15. 